\title{
How to map a plantain: phylogeny of the diverse Plantagineae (Lamiales)
}

SHIPUNOV, ALEXEY ${ }^{1}$; FERNÁNDEZ A., JOSÉ LUIS², HASSEMER, GUSTAVO³ ; ALP, SEAN;

LEE, HYE JI ${ }^{1}$; PAY, KYLE ${ }^{1}$

${ }^{1}$ Department of Biology, Minot State University

${ }^{2}$ Real Jardín Botánico, CSIC, Madrid, Spain

${ }^{3}$ Federal University of Mato Grosso do Sul, Três Lagoas Campus, CEP 79610-100, Três Lagoas, MS, Brazil

The tribe Plantagineae (Lamiales) is a group of plants with worldwide distribution, notorious for its complicated taxonomy, still unresolved natural history, and a trend of morphologic reduction and simplification. This tribe includes the plantains (Plantago), the small aquatic Littorella, and the northern Andean shrubs Aragoa. Some Plantago lineages exhibit remarkably high diversification rates, which further adds to the complicated classification, and the worldwide distribution of these plants raises numerous questions related to vicariance and dispersal. In this work, we present the broadest phylogeny of the group to date and discuss the evolutionary, morphological, and biogeographical implications of our phylogenetic results, including the description of two new species from the Americas. 


\section{INTRODUCTION}

The tribe Plantagineae (Lamiales) consists of well-known, worldwide distributed plantains (Plantago), small aquatic Littorella, and Andean (mostly Colombian) páramo shrubs Aragoa. This group of plants is notorious for its complicated taxonomy, still unresolved natural history and a trend of morphologic reduction and simplification (Fernández, 1995; Rahn, 1996; Rønsted el al., 2002; Hassemer et al., 2019). Therefore, the elucidation of the phylogenetic relationships within this tribe is of high importance not only for taxonomic classification but also for phytogeography and our general understanding of plant evolution.

Plantains (ribworts), Plantago L., are remarkable plants. They grow almost everywhere all around the world, except for the Antarctic and tropical wet forests (Rahn, 1996; Hassemer et al., 2016). Morphologically, they bear the unusual combination of characters (Linnaeus, 1754): sympetalous 4merous non-showy flowers developing into circumscissile capsule-like fruit (pyxidium), and monocotlike leaves with arcuate or parallel venation, usually borne in a rosette. Even in times when only sixteen species were described in Plantago, botanists mentioned a remarkable similarity between different species (Linnaeus, 1753); this typically results in a significant amount of incorrectly determined specimens, even in leading herbarium collections. Plantains exhibit some of the terminal stages of morphological reduction among Lamiales, and recent research (Preston et al., 2011) demonstrated how this flower reduction could happen within Antirrhinum-Plantago lineage. There is also a reduction of vegetative characters expressed in many plantains, and only a few species have a branched stem and "dicotyledonous" leaves. In all, evolution towards anemophily resulted in significant morphological convergence with graminoid monocots.

Geographic distribution of Plantago is exceptionally broad, and this is due not only to cosmopolitan weeds $P$. lanceolata L. and P. major L. On many remote ocean islands, for example, there are unique species of Plantago, and some of them exhibit a remarkable tendency to evolve into woody plants 
(Carlquist, 1970; Iwanycki Ahlstrand et al., 2019). As a whole, Plantago likely underwent a rapid (Cho et al., 2004) evolution and recent (Meudt et al., 2015) diversification. Many new Plantago species have recently been discovered and described, most of them rare and narrowly distributed (e.g., Hassemer and Rønsted, 2016; Hassemer et al., 2018a; Hassemer 2019). All of the above makes Plantago a group of plants with considerable interest for biodiversity conservation (Hassemer et al., 2016). Furthermore, Plantago is a complicated genus also from a nomenclatural point of view (Di Pietro et al., 2013; Doweld and Shipunov, 2017; Hassemer, 2018a, 2018b), and many problems remain to be solved. Aquatic Littorella P.J.Bergius (Bergius, 1768) comprises three species with considerably disjunct distribution; they grow in shallow waters of North America Great Lakes, Patagonia, and Northern Europe (here both in lakes and desalinated North and Baltic seas). These plants are morphologically similar to Plantago, and Rahn (1996) joined two genera. However, when molecular data started to be available (Hoggard et al., 2003), Plantago and Littorella were shown as sister clades, and since then nearly all authors preferred to keep the tradition of recognizing the two genera as separate.

Contrary to Plantago and Littorella, woody shrubs Aragoa Kunth (Kunth, 1818) are the local endemics of páramo in Colombia (one species also in Venezuela). Until the first molecular results (Bello et al., 2002), it was never considered to be a sister group for Plantago + Littorella clade but rather unplaced in “old” Scrophulariaceae (Fernández, 1995). Aragoa is relatively speciose, containing more than 20 described species and also several hybrids (Fernández, 1993, 1995), whereas no hybrid species have been described in two other genera. The hybridization might explain the rapid radiation and speciation in this genus (Fernández, 2002). Flowers of Aragoa are likely animal-pollinated (Fernández, 1995) but actinomorphic, and leaves are reduced, similarly to two other genera of the group (Bello et al., 2004).

Plantago, Littorella and Aragoa form well-supported (both morphologically and molecularly), stable clade (Bello et al., 2002; Rønsted et al., 2002; Bello et al., 2004; Meudt et al., 2015) which we call hereafter the tribe Plantagineae Dumort. (Dumortier, 1829). Multiple detailed morphology-based 
works were published about Plantagineae; most important are Barnéoud (1845), Decaisne (1852), Pilger (1937), Fernández (1995), and Rahn (1996). However, the comprehensive molecular study based on the broad sampling of this whole group is still absent. The broadest at the moment are works of Rønsted et al. (2002) and Hoggard et al. (2003), which included 59 and 27 species, respectively (whereas the group is estimated to include ca. 250 species). To compare further, the GenBank database as of June 2019 contains only about 140 species entries (and this does not account for possible synonymy). This situation has shown signs of improvement lately, and several publications which cover the complicated Plantago subg. Plantago (e.g., Hassemer et al., 2019; Iwanycki Ahlstrand et al., 2019) and subg. Coronopus (Höpke et al., 2019; Hassemer et al., 2017; Hassemer 2018b) are now available. Some recent regional works (Tay et al., 2010; Meudt, 2011, 2012) also improved our knowledge of subg. Plantago. However, no recent molecular works are focusing on Aragoa diversity, and since Rønsted et al. (2002), nothing significant was published about molecular taxonomy of Psyllium and allies (we include here subgenera Bougueria, Psyllium s.str. and Albicans).

Therefore, we consider Plantagineae the under-studied group, especially in the molecular aspect. This situation dictates the necessity of the molecular phylogenetic study with the broadest sampling in mind. We continue the line of Rønsted et al. (2002) and employ similar barcoding markers but aim for the greater species coverage, with the ultimate goal to assess all described species of the group and obtain the most detailed picture of their relationships. Together with molecular characters, we employ morphological characters identified in Rahn (1996) and morphometric characters from samples used in molecular studies. Our goal was also to solve multiple problems with the Plantagineae taxonomy and geography, whose resolution will improve the overall understanding, help in conservation, ecology, and invasive biology studies, and will ease the identification of Plantagineae species which still is a tedious and difficult task, especially for beginners. 


\section{MATERIAL AND METHODS}

\section{PLANT MATERIAL}

It is virtually impossible to sample 250 species (Support Table 1) without the help of the herbarium collections. Plantagineae is infrequently cultivated, and re-collection from nature, especially herbaceous short-living plants, is a task that is successful only rarely (e.g., Hassemer et al., 2018a). Therefore, while some of our samples were collected into silica gel from the living plants, the majority of work (94\%) involved tissue samples taken (with the kind permission of herbarium curators) from plants collected years ago.

Using herbarium samples poses some restrictions. While the purity and concentration of DNA do not significantly suffer from time (Choi et al., 2015), the quality of sequences heavily depends on sample age, collection methods, and the nature of fragment to amplify. With older sample age, more difficult drying process, and longer fragment, our chances to obtain the useful data were significantly lower.

Since not every sample yields reliable DNA, we typically collected multiple samples per species and attempted to extract and sequence it numerous times. Now we have sequences of at least one DNA marker from 220 species (including 192 Plantago species). Data from 86 species have been taken from public databases. In all, we were able to increase the amount of available information three-fold (fourfold in Aragoa). Due to the apparent problems with identification (Funk et al., 2018), we always trusted our samples first.

\section{DNA SEQUENCING}

DNA extraction performed using multiple standard protocols, but soon after the start of the project (2011), we decided to stay with NUCLEOSPIN Plant II Kit (MACHEREY-NAGEL GmbH \& Co. KG, Düren, Germany) which seems to be is a good trade-off between efficiency and simplicity. We improved this protocol in several points, e.g., increased the lysis time to $30 \mathrm{~min}$ and used thermomixer 
on the slow rotation speed $(350 \mathrm{rpm})$ instead of a water bath. To assess DNA quality, we used Nanodrop 1000 Spectrophotometer (Thermo Scientific, Wilmington, DE, USA), which estimates concentration and purity (the $260 / 280 \mathrm{~nm}$ ratio of absorbance) of samples. Typically, 1.4 ratio was enough to guarantee PCR amplification of smaller markers, whereas the ratio 1.7 was an average in the group. The lower DNA quality was typically obtained from samples presumably collected in wet climates.

Especially low was the quality of our Aragoa samples; this might be due to the widespread use of drying cabinets, the theory which indirectly supported with good results which we obtained from samples dried without any help (even without silica gel), just in room conditions in Bogotá. Reversely, we sometimes were able to extract, amplify, and sequence samples collected long ago, e.g., from Plantago sinaica Decne. collected in 1834 !

Nevertheless, short barcoding DNA markers (Kuzmina and Ivanova, 2011) are the best to amplify for herbarium samples; therefore, our first choice was nuclear ITS2 and chloroplast $t r n$ L-F spacer and $r b c \mathrm{~L}$ gene. We amplified them following the Barcoding of Life recommendations and protocols (Kuzmina and Ivanova, 2011). Several samples were sequenced with the direct help of Barcoding of Life ("SAPNA" project); this last project provided us also with sequences of mitochondrial COI and plastid matK markers.

Typically, our PCR the reaction mixture had a total volume of $20 \mu \mathrm{L}$ which contained $5.2 \mu \mathrm{L}$ of PCR Master Mix (components mostly from Thermo Fisher Scientific, Waltham, Massachusetts supplied with Platinum DNA Taq Polymerase), $1 \mu \mathrm{L}$ of $10 \mu \mathrm{M}$ forward and reverse primers, $2 \mu \mathrm{L}$ of DNA solution from the extraction and 10.8 $\mu \mathrm{L}$ of MQ purified water (obtained from a Barnstead GenPure Pro system, Thermo Scientific, Langenselbold, Germany) in the TBT-PAR water mix (Samarakoon et al., 2013). The latter was developed to improve amplification from the herbarium samples. Thermal cycler programs were mostly $94{ }^{\circ} \mathrm{C}$ for $5 \mathrm{~min}$, then 35 cycles of $94{ }^{\circ} \mathrm{C}$ for $1 \mathrm{~min} ; 50-52^{\circ} \mathrm{C}$ (depending 
on the primer) for $1 \mathrm{~min}, 72^{\circ} \mathrm{C}$ for $2 \mathrm{~min}$, and finally $72{ }^{\circ} \mathrm{C}$ for $10 \mathrm{~min}$. PCR products were sent for purification and sequencing to Functional Biosciences, Inc. (Madison, Wisconsin) and sequenced there under standard Sanger-based protocol. Sequences were obtained, assembled, and edited using Sequencher ${ }^{\mathrm{TM}} 4.5$ (Genes Codes Corporation, Ann Arbor, Michigan, USA).

\section{PHYLOGENETIC ANALYSES}

Subsequent steps use the "Ripeline" workflow. This workflow is the collection of UNIX shell and R (R Core Team, 2019) scripts that automate steps related to sequence selection, quality checking, alignments, gap coding, concatenation, and phylogenetic tree production. Ripeline involves multiple pieces of software, for example, AliView (Larsson, 2014), MUSCLE (Edgar, 2004), APE (Paradis et al., 2004), MrBayes (Ronquist and Huelsenbeck, 2003), ips (Heibl, 2008), shipunov (Shipunov et al., 2019), and phangorn (Schliep, 2011).

With the help of Ripeline, we were able to obtain maximal parsimony (MP) and Bayesian (MB) phylogenetic trees. MP analyses run with the help of the R phangorn package (Schliep, 2011) using parsimony ratchet (Nixon, 1999) with 2000 iterations and then 1000 bootstrap replicates. MB analyses run through the combination of MrBayes 3.2.6, and $\mathrm{R}$ ips and shipunov packages (Ronquist and Huelsenbeck, 2003; Heibl, 2008; Shipunov, 2019b). MCMC analysis (2 runs, 4-8 chains) was run for $1,000,000$ generations, sampling every 10 th generation resulting in 100,000 trees, and checked for the convergence. The first $25 \%$ of trees discarded as burn-in and the remaining trees summed to calculate the posterior probabilities. With the aid of R ape package (Paradis et al., 2004), all trees rooted with Veronicastrum virginicum (L.) Farw. and Tetranema roseum (M.Martens \& Galeotti) (= Tetranema mexicanum Benth.) as outgroups, or with the $V$. virginicum alone.

Our phylogenetic trees use two data sets. Since all single marker trees were concordant, we used (with the help of Ripeline) the super-matrix approach. Our first data set included multiple barcoding markers available from public databases and our sequencing, which is chloroplast $r b c \mathrm{~L}, t r n \mathrm{~L}-\mathrm{F}, m a t \mathrm{~K}$, and also 
nuclear ITS and mitochondrial COI. We call this dataset "broad" since it is relatively rich in data but has a limited sampling along the species dimension (87 entries and $4188 \mathrm{bp}$, including 656/497/561/1565/909 bp in COI, ITS2, $r b c \mathrm{~L}, \operatorname{trn} \mathrm{L}-\mathrm{F}$ and $m a t \mathrm{~K}$, respectively). The second dataset was made with the broadest species coverage but included only ITS2 and trnL-F data, which is originated mostly from our sequencing efforts. Below, we designate it as "tall” (273 entries, including some subspecies and forms and $2062 \mathrm{bp}$ length, including the same ITS and trnL-F fragment lengths as above).

\section{MORPHOMETRICS}

Ripeline is also capable of using morphological characters, and we employed the updated and expanded morphological dataset from Rahn (1996) to make combined (molecules + morphology) and pure morphological datasets. To make Rahn's (1996) dataset digital, we OCR'ed and cleaned the text, tables from it were converted into spreadsheets and merged.

To emphasize the weight of morphological characters, we used the hyper-matrix approach (Ashkenazy et al., 2018) and multiplied morphological dataset several times in order to achieve the approximate equality between numbers of molecular and morphological characters. We added characters of seed sculpture (Shipunov, 1998a, 1998b; Shehata and Loutfy, 2006) to the characters used in Rahn (1996), and expanded the dataset with species absent in the last work. In total, our binary morphological matrix has 114 characters and 271 entries.

We also were able to use the measurements of seven most apparent morphometric characters of Plantago: petiole, leaf, spike, and scape lengths, maximal leaf width, presence of taproot, and looseness ("gaps") in the inflorescence. In total, we measured these characters on 405 herbarium samples (same which were in DNA extraction).

Using morphological, morphometric and DNA datasets, we were able to perform the broad spectrum of 
statistical analyses, including Procrustes analysis of the correspondence between molecular and morphological information (Peres-Neto and Jackson, 2001; Balbuena et al., 2013) and nearest neighbor machine learning (Ripley, 1996) for the placement of under-studied taxa. As an additional source to use in the placement process, we employed the combined molecular + morphology phylogenic tree.

We also employed the recursive partitioning (Venables and Ripley, 2002; Höpke et al., 2019), the machine learning technique which takes the classification and creates binary trees for the rest of data set. The structure of these trees is similar to the dichotomous keys (Therneau et al., 2014). Naturally, results of recursive partitioning are applicable for the construction of the dichotomous keys, which could help in the discrimination of Plantago sections and species.

Datasets, scripts, and phylogenic trees used in the preparation of this publication are available from the first author's Open Repository here: http://ashipunov.info/shipunov/open/plantago.zip. Ripeline is available on Github: https://github.com/ashipunov/Ripeline. We encourage readers to reproduce our results and develop our methods further. All sequences were deposited into the GenBank.

In the paper, we followed the "appropriate citation of taxonomy" (ACT) principle (Seifert et al., 2008) and cited names of the most supra-species groups (Reveal, 2012).

\section{RESULTS}

\section{PLANTAGINEAE IN GENERAL}

All trees based on "broad" and "tall" datasets returned the stable (Aragoa, (Littorella, Plantago)) topology (Fig. 1), typically with the longest branch leading to Aragoa. As our maximum parsimony (MP) trees do not differ significantly from Bayesian (MB) trees, we hereafter present the results (Fig. 1-5) based mostly on the second type of analysis. 
Generally, the stability of subclades is not high in Aragoa (Fig. 2). The most stable is a placement of Aragoa lucidula S.F.Blake as a sister to all other studied Aragoa species. Within the rest of the subtree, the majority of species make one clade with subdivisions mostly without high support.

Morphologically outstanding $A$. dugandii Romero forms the clade with $A$. lycopodioides Benth. and $A$. occidentalis (all branches here are significantly longer than in other parts of Aragoa tree). The other unusual species, A. perez-arbelaeziana Romero, forms a clade with A. romeroi Fern.Alonso (Fig. 4, $5 \mathrm{~A})$.

\section{LITTORELLA}

Three (two in the "broad" dataset) species of Littorella make the stable group where European $L$. uniflora (L.) Asch. is sister to American L. americana Fernald and L. australis Griseb. ex Benth. \& Hook.f.

\section{PLANTAGO IN GENERAL}

There is relatively high support for three major subdivisions of Plantago, which correspond with subgeneric rank. The topology is robustly (Psyllium s.1., (Coronopus, Plantago)), or in more detail, ((Bougueria,(Psyllium s.str., Albicans)), (Coronopus, Plantago)). Subgenera Plantago, Coronopus, and Psyllium clade form the remarkable "three-ridge" phylogenetic density surface (Fig. 3).

\section{PlantaGo SUBG. PLANTAGO}

Only trees originated from the "broad" dataset have relatively high support for clades within this group, whereas "tall" trees have the reliable support only for some terminal clades (Fig. 2, 4, 5B-D).One of the most stable groups consists of $P$. media L., P. canescens Adams, P. arachnoidea Schrenk ex Fisch. \& C.A.Mey., P. krascheninnikovii C.Serg., P. maxima Juss. ex Jacq., P . perssonii Pilg. and $P$. schwarzenbergiana Schur. Tetraploid, xeromorph variant of $P$. media described as $P$. urvillei Opiz ( $P$. media subsp. stepposa (Kuprian.) Soó), typically does not branch with P. media s.str. 
Plantago krascheninnikovii from the Urals is habitually similar to the inland forms of P. maritima L.(however, it lacks the key feature of subg. Coronopus, i.e., pilose corolla tube). On our trees, it groups with P. arachnoidea from Central Asia. Chinese Plantago perssonii Pilg. (including P. lorata (J.Z.Liu) Shipunov described from Central Asia: Shipunov, 2000a) robustly groups with P. arachnoidea.

Morphologically unusual $P$. reniformis Beck from Balkans frequently also groups here with low support.

Another stable group consists of species from sect. Micropsyllium: Palearctic P. polysperma Kar. \& Kir., P. tenuiflora Waldst. \& Kit., and Nearctic P. elongata Pursh, P. heterophylla Nutt. and P. pusilla Nutt. Here we noted that geographically isolated, perennial $P$. tenuiflora from Öland (first described as separate species $P$. minor Fr.) does not group with typical $P$. tenuiflora but instead groups with $P$. polysperma.

The less stable but relatively consistent group forms around polymorphic $P$. asiatica L. from mainland China and Japan, including P. schneideri Pilg., P. centralis Pilg., and P. cavaleriei H.Lév. We found typical P. asiatica on Hawaii Island, thus extending the range of this East Asian species to mid-Pacific. However, all "P. asiatica" from mainland USA are either P. major or P. rugelii Decne. (Shipunov, 2017, 2019a).

Plantago hakusanensis Koidz. is a Japanese alpine endemic species with a distinct morphology. On our trees, it is branched closely to $P$. asiatica. In PE herbarium, we discovered the Yunnan sample labeled as "Plantago zhongdainensia" (nomen nudum), which morphologically might be considered similar to both $P$. hakusanensis and P. asiatica. Unfortunately, DNA data is not available from this sample. Proximal to $P$. asiatica is also morphologically distinct $P$. hasskarlii Decne. from Java mountains. Another species from Southeast Asia, P. incisa Hassk., groups outside of P. asiatica clade(s).

The unusual form collected from China is morphologically somewhat similar to the $P$. densiflora J.Z.Liu (synonymized with $P$. asiatica in the "Flora of China," Li et al., 2011). However, this form, 
“Plantago sp. Hupeh1” has typically 4-6 large black seeds (and also large fruits), which is not in agreement with $P$. densiflora protologue. On our trees, it groups with $P$. depressa Willd. and allies (e.g., P. komarovii Pavlov and P. camtschatica Link). Besides, on "broad" trees, $P$. depressa robustly groups together with P. macrocarpa Cham. \& Schltdl.; this grouping is also present on "tall" trees with less support.

American P. eriopoda Torr., P. rugelii, P. sparsiflora Michx., and P. tweedyi A.Gray robustly supported as a clade on "broad" trees. Here belong also two samples collected in Chihuahua desert (BRIT) from northern Mexico; these plants have many morphological differences from other species in this group but cluster together with $P$. eriopoda and $P$. tweedyi. Plantago rugelii, which morphologically is hard to tell from $P$. major, doest not group with this last species on any tree; these two species found to belong to different sections (Hassemer et al., 2019).

Plantago major does not branch closely to P. asiatica, which was pointed out in Hassemer et al. (2019). Instead, P. major s.1. groups with P. japonica Fr. \& Sav., P. cornuti Gouan, P. gentianoides Sibth. \& Sm. and $P$. griffithii Decne., albeit with low support. Sequences from polyspermous form of $P$. major (Morgan-Richards and Wolff, 1999) described as P. uliginosa F.W.Schmidt, are identical to the typical P. major. Plantago griffithii, which is frequently considered a form of P. gentianoides groups with the last species (in a strict sense) on our trees, but this grouping is unstable.

Plantago pachyphylla A.Gray and P. hawaiensis (A.Gray) Pilg. (both from Hawaii) group together, and also with $P$. aundensis P.Royen from New Guinea. Alpine form of P. pachyhylla from Kauai (labeled in HUH as "Plantago nubicola Tessene," nomen nudum) clusters outside of P. hawaiensis $+P$. pachyphylla from Hawaii island.

Two New Zealand species, $P$. triandra Berggr. and P. unibracteata Rahn, always cluster together outside of the rest of subg. Plantago. 
Our phylogenic trees, especially from the "tall" dataset, also provide the primary ground for the placement of little-studied or previously molecularly not studied forms, for example, for P. laxiflora Decne. This South African species is morphologically unusual for the region and groups outside of African species. Other African and Madagascan species, i.e., P. africana Verdc., P. longissima Decne., P. palmata Hook.f., P. remota Lam. and P. tanalensis Baker, tend to group with small support.

Most of Plantago sect. Virginica species do not group with high support. However, we note that Andean $P$. oreades Decne. always branches outside of the P. australis Lam. group. Another Peruvian form from this section was listed by Knud Rahn (MO herbarium note) as possible new species; on our trees, it groups with different members of the section, including South American P. tomentosa Lam. The second "unknown" from Peru, sect. Virginica sample from NY with a long stem (unusual in subg. Plantago) frequently groups with P. tenuipala (Rahn) Rahn from Columbia.

Plantago firma Kunze ex Walp. was typically considered as strictly Chilean species, but we have found its samples collected in Peru (USM). All Chilean and Peruvian P. firma samples robustly group together, and then with another species, bipolarly distributed P. truncata Cham. \& Schltdl.

While there is a little confidence among branches which belong to the rest of sect. Virginica, we were able to place in that group molecularly those species which have not been sampled before, namely $P$. argentina Pilg., P. berroi Pilg., P. buchtienii Pilg., P. dielsiana Pilg., P. floccosa Decne., P. jujuyensis Rahn, $P$. orbignyana, $P$. penantha Griseb., P. tenuipala (Rahn) Rahn, $P$. ventanensis Pilg. and $P$. venturii Pilg.

Knud Rahn's series Oliganthos species (P. barbata G.Forst., P. correae Rahn, P. pulvinata Speg., $P$. sempervivoides Dusén, and P. uniglumis Wallr. ex Walp.) were sequenced the first time as a totality. On our "tall" trees, the group does not have high support but clusters together with $P$. moorei Rahn, $P$. tehuelcha Speg. and P. fernandezia Bertero ex Barnéoud, all from South America’s Cone and surrounding islands. 
Most of the Australian species form a low supported but relatively stable grade; here we were able to place some under-researched species: $P$. antarctica Decne., $P$. depauperata Merr. \& L.M.Perry, $P$. drummondii Decne., P. gunnii Hook.f., P. polita Craven (New Guinea) and P. turrifera B.G.Briggs \& al.

\section{PLANTAGO SUBG. CORONOPUS}

On this stable trees (Fig. 4, 5B), the topology always supports the subdivision of sects. Maritima and Coronopus. Within sect. Maritima, we were able to place with confidence the rare Central Asian $P$. eocoronopus Pilg. (as a sister to the whole group) and North African P. rhizoxylon Emb. We detected the presence of the "true" P. maritima in South Africa (PRE herbarium); these samples are molecularly not different from the rest of $P$. maritima.

Macaronesian P. asphodeloides Svent. is the sister to other species from sect. Coronopus, and North African P. crypsoides Boiss. is sister to Mediterranean P. serraria L.

\section{PLANTAGO SUBG. PSYLLIUM AND ALLIES}

Within this stable group (Fig. 4, 5D), P. nubicola (Decne.) Rahn (which sometimes regarded as a separate genus Bougueria) is always branching basally. The following topology is prevalent: (Psyllium s.str., ("American clade," "Plantago ciliata clade," "Mediterranean clade")); these we will describe in detail below.

Psyllium s.str. forms a robust, relatively long branch that split between mostly annual species with nonlinear bracts (e.g., P. squarrosa Murray) and mostly perennial, woody species with narrow bracts (e.g., P. arborescens Poir.).

"Plantago ciliata clade" on "tall" trees is sister to "American clade", whereas on "broad" trees $P$. ciliata Desf. is sister to "Mediterranean clade" (with lower support). This clade includes $P$. ciliata and two successfully sampled species from the sect. Hymenopsyllium, i.e., P. cretica L. and P. bellardii All. 
"American clade" is, in essence, Rahn's sect. Gnaphaloides. Plantago erecta E.Morris is variably at the base of this group, and $P$. helleri Small branches close to the southern $P$. nivea Kunth. The rest of North American species form a stable clade (which therefore roughly corresponds with Rahn's ser. Gnaphaloides), where P. aristata Michx. and P. argyrea E.Morris form a subgroup.

On "tall" trees (where sampling is reliable), species from Central and South America form the $P$. tandilensis (Pilg.) Rahn + P. brasiliensis Sims + P. bismarckii Nederl. clade, P. grandiflora Meyen clade, P. sericea Ruiz \& Pav. grade (incl. P. lamprophylla Pilg., P. nivea, P. helleri, P. linearis Kunth, and $P$. tolucensis Pilg.) and ser. Hispiduleae clade. The latter also includes $P$. johnstonii Pilg. and samples of $P$. litorea Phil. collected in Peru (thus extending the range of this Chilean species). Samples of some $P$. sericea subspecies do not branch together with the bulk of $P$. sericea samples (Fig. 5D).

“Mediterranean clade" corresponds with sects. Montana, Lancifolia, and Albicans (except P. ciliata). The first subclade formed with members of the first two sections plus $P$. lagocephala Bunge and two species from the sect. Albicans ser. Minutae: P. minuta Pall. and P. lachnantha Bunge. Sections Montana and Lancifolia represented as proposed by Rahn (1996) except for P. loeflingii L. (it groups with sect. Lancifolia instead of sect. Montana).

"Mediterranean clade" 2nd subclade consists mostly of species from the sect. Albicans. Plantago amplexicaulis Cav. (sect. Bauphula) and P. stocksii Boiss. ex Decne. (sect. Albicans ser. Ciliatae) group together on the base of this group. The next branch(es) is $P$. ovata Forssk. and P. psammophila Agnew \& Chal.-Kabi + Ethiopian P. annua. The rest of this subclade consists of species from ser. Albicantes and Ciliatae, plus P. notata Lag.

\section{MORPHOLOGICAL AND COMBINED ANALYSES}

The Procrustes analysis allows for the embedding of two multivariate datasets (Peres-Neto et Jackson, 2001; Balbuena et al., 2013) and related statistical tests. Our molecular and morphological datasets are 
significantly correlated (correlation $=0.7748$, significance $=0.001$ based on 999 permutations), but individual placements are variably shifted (Fig. 6).

Even after intensive sampling, some species of the group still lack the molecular information. There are also species where only ITS2 sequences are available. With $k$-nearest neighbor machine learning (Fig. 7), we obtained the section/series placements of these Plantago species. More than half of them placed with high (>90\%) bootstrap confidence (Table 1). In the case of Aragoa, we only operated with an existent classification (Fernández, 1995) combined with phylogenic trees, and our placements here structured as trios of the most closely related species (Table 1).

Chi-squared tests returned the appropriate p-values when comparing leaf shapes (morphometric dataset) with subgenera, sections, and macro-regions $(0.0005,0.016$, and 0.0055 respectively) and typically large effect sizes (corrected Cramer's V 0.39, 0.34 and 0.26 respectively, see also Fig. 8). At the same time, the relative sizes of the stalk and spike were not significant. There is also a support for the pattern of gapped spike vs. sections (p-value 0.0004 and 0.48 corrected Cramer's V).

We used the average or maximum Spearman correlation between morphological matrices and phylogenetic trees based either on a "tall" dataset or molecular-morphological dataset to determine the "molecular weight" of morphological characters. Most "heavy" among morphometric characters Fig. 9A) was the presence of taproot, and then the length of leaves (Fig. 9B). The top 10 binary morphological characters (Fig. 9C) were: seed surface type 4 (with elongated ridges: Shipunov, 1998b), long corolla ( $>4 \mathrm{~mm}$ or $>3 \mathrm{~mm}$ ) lobes, opposite leaves, presence of pedicel, truncated base of leaf blade, presence of glandular hairs, elongated stem, antrorse hairs on the stalk, and presence of nonglandular hairs with the strongly refracted walls.

We used recursive partitioning (Venables et Ripley, 2002) to construct the classification trees of the group (Fig. 10A-B). With binary morphological binary characters, we employed three runs, excluding characters used in the previous run. The resulting recursive classification trees employed 20, 20, and 19 
characters (out of 115) and had 25.3\%, 35.5\%, and 48.1\% misclassification errors, respectively. With morphometric characters, the resulted tree used all seven characters and returned a $75.5 \%$ misclassification error.

\section{DISCUSSION}

\section{PLANTAGINEAE}

There is unequivocal support for the Aragoa (Littorella (Plantago)) structure of the group phylogeny (Fig. 1, 2, 4). This structure is concordant with the current understanding of the evolution of the tribe, including the evolution of flower symmetry (Preston et al., 2011). Reduced leaf morphology might also be explained with this phylogeny.

Bello et al. (2012) included only three species (plus two hybrids) of Aragoa and did not resolve their relationships. Here for the first time, the significant part of the Aragoa diversity was reviewed using the data obtained in molecular research (Fig. 4, 5A). In general, there is some support for grouping obtained in the research solely based on morphology (Fernández, 1995).

However, some morphologically unusual species like $A$. dugandii with relatively broad leaves, and $A$. perez-arbelaeziana with long tubular flowers do not make separate clades but are clustered together with more "typical" species (A. lycopodioides and A. romeroi, respectively, both from the main clade). The relatively broad, patent leaves and the simple inflorescence of $A$. dugandii, together with relatively large flowers, might be therefore interpreted as an adaptation to environments where moisture loss is not so critical as for many other species of the genus. As for A. perez-arbelaeziana, the presence of long, pendulous, yellowish corollas, unusual in the genus, can be interpreted as a result of recent adaptive radiation to a specific type of pollinator (hummingbirds: Fernández, pers.obs.) which does not entail the significant modifications in vegetative structures. 
The machine learning placement of three unsampled Aragoa species resulted in the selection of possible "candidate neighbors" (Table 1) from the same main Aragoa clade.

Littorella, with three distinct species lineages, is robustly supported as a sister group of Plantago. Our data (Fig. 4, 5A) agree with a view of morphologically and ecologically outstanding Littorella as a separate generic lineage (Hoggard et al., 2003).

Plantago taxonomy is the most complicated part of our research. In general, there are no significant conflicts with the most recent studies of the genus based on morphology summarized in Rahn (1996). However, there are numerous findings and differences to emphasize.

All our analyses reproduce ((Coronopus, Plantago), Bougueria, (Psyllium, Albicans)) backbone (Fig. 4, 5B-D). Based on our trees, it is possible to keep the latter three subgenera as such based on strong molecular and morphological support. Alternatively, it is also possible to lump two last groups in one subg. Psyllium (Rønsted et al., 2002). Apart from the molecular evidence, this Psyllium s.l. union has reliable morphological support: two (rarely one) ovules and seeds, cotyledons perpendicular to the placenta, placenta side of seed deeply concave, hairs with a basal cell shorter than broad, leaves are often linear and spike usually relatively short (Rahn, 1996). The third alternative would be to accept this union as a separate genus, Psyllium Mill. s.1. (Shipunov, 1998a, 2000a), but this will significantly decrease the nomenclatural stability in the group.

\section{Plantago SUBG. PLANTAGO}

In general, our trees in this part (Fig. 5B, 5C) do not provide a clear, well-resolved picture as in plastome studies (Hassemer et al., 2019). However, they contain new information about possible placements of previously not molecularly studied species, and also about species which were not included in plastome research. In several cases (Hassemer et al., 2019), the position of species in the specific section was "inferred based on the accumulated knowledge." Many of such species are now 
more formally distributed between these sections (Table 1), and this is reflected in our working classification of Plantagineae (Support Table 1).

For example, it is mentioned in Hassemer et al. (2019) that “...based on our phylogeny it is impossible to infer the position of the five unsampled American species in Rahn's (1996) series Oliganthos (P. barbata, P. correae, P. pulvinata, P. sempervivoides, and P. uniglumis)". Our current trees (Fig. 5C) place these species (except $P$. correae for which we have no data) in one clade, which also includes $P$. rigida, $P$. tubulosa, $P$. moorei, $P$. tehuelcha, and $P$. fernandezia, the placement which is well justified geographically. Morphologically unusual P. sempervivoides is sister to the remainder of the group. Two sect. Carpophorae species are sister to P. fernandezia $+P$. barbata. This group likely has an Andean origin, and P. fernandezia might, therefore, arrive at Juan Fernández from South America (Stuessy et al., 2017; Iwanycki Ahlstrand et al., 2019). Position of P. fernandezia, P. tehuelcha, and sect. Carpophorae species are different on the plastome trees (Hassemer et al., 2019), but these trees have low support exactly in these parts.

Another complicated group was not resolved entirely, but we provide several insights for the placements and phylogeny in general of species around polymorphic and widespread $P$. asiatica (Matsuo, 1989, Ishikawa et al., 2006; Ishikawa et al., 2009). Most of these forms cluster together (Fig. 4, 5C) and separately from the P. major clade; thus, morphological similarity here does not justify taxonomic closeness. Japanese endemic Plantago hakusanensis is either within this group or branches basally; the same is true for P. hasskarlii. Relations of P. hakusanensis and P. hasskarlii mandate more in-depth research.

Molecular data from Plantago japonica, together with ecology and morphology, suggests that this species is likely distinct from P. major (Matsuo, 1989; Ishikawa et al., 2009).

Samples from the Hubei province of China ("Plantago sp. Hupeh1”) have an appearance of Plantago asiatica but branch near P. komarovii + P. camtschatica clade (Fig. 5B). As the allopolyploid origin of 
tetra- or hexaploid $P$. asiatica and $P$. rugelii was suggested by Ishikawa et al. (2009), we cannot exclude the possibility of the allopolyploid origin of these Hubei samples (with ITS kept from the sect. Pacifica parent). We believe that a thorough study of Chinese, Korean, and Japanese Plantago subg. Plantago species is required before reaching any robust conclusions. In the light of Ishikawa et al. (2009) report, the recent historical origin of $P$. rugelii (which branches closely to $P$. sparsiflora on our trees but morphologically hardly distinguishable from $P$. major) might also be justified.

There are seven endemic Plantago species described from New Guinea (P. aundensis, P. depauperata, P. montisdicksonii P.Royen, P. papuana P.Royen, P. polita, P. stenophylla Merr. \& L.M.Perry and $P$. trichophora Merr. \& L.M.Perry), but DNA extraction from available samples failed in 90\% of cases. Nevertheless, we were able to place four of these species (Fig. 5B): P. aundensis with Hawaiian $P$. pachyphylla s.l. and P. hawaiensis (the third Hawaiian species, $P$. princeps does not hold a stable position on our trees); P. depauperata and P. polita with Australian P. muelleri Pilg.; and P. trichophora with Australian P. gaudichaudii Barnéoud. Still, much more sampling is needed, and Hawaiian species also deserve a closer look (Hassemer et al., 2019).

Morphologically unusual samples (Fig. 11) from Chihuahua (Mexico) are physiognomically similar to P. gaudichaudii from Australia and P. remota from South Africa, but we believe that it is the clear example of morphological convergence. On our trees, these samples belong to sect. Pacifica clade and branch together with Midwestern P. eriopoda and P. tweedyi from the Rocky Mountains region (Fig. 5B). 
The same Pacifica clade includes on "broad" trees Plantago macrocarpa, the Northern Pacific seashore species. On the "tall" trees (Fig. 5B), the placement of this species is not stable.

Plantago krascheninnikovii is superficially similar to the inland forms of P. maritima and therefore treated as a member of subg. Coronopus (Shipunov, 2000b). Known populations of this rare Urals species do not typically form the ripe seeds (Shipunov, 1998a), thus preventing the correct placement on the base of morphology. Here we the first time confirm its similarity with other Lamprosantha species, for example, Eastern European P. schwartzenbergiana (Fig. 5C).

The southern tetraploid forms similar to Plantago media but with thick, erect, grayish leaves (Shipunov, 1998a, 2000b), often regarded as P. urvillei Opiz or P. media subsp. stepposa (Kuprian.) Soó, are distant from P. media s.str. (Fig. 5C), thus necessitating the separation of this taxon. However, the diversity of P. media s.l. is still far from being fully understood (Palermo et al., 2010), and more research is needed to draw robust taxonomic conclusions. Here should be noted that P. media subsp. stepposa must not be mixed with the similarly looking shade, mesophytic plants of $P$. media (Shipunov, 1998a). 
Small perennial sect. Micropsyllium plantains from Öland described as P. minor Fries are

morphologically distinct and geographically isolated from other species of this section. However, common garden experiments (Tsinger, 1905) led to the conclusion that they are conspecific with $P$. tenuiflora while our Öland sample is proximal to $P$. polysperma. We believe that more research on Öland plantains is needed to understand the taxonomic status of these forms better.

Andean Plantago oreades Decne. with distinct morphology (narrow leaves, long inflorescences, broad bracts, 1-3 seeded fruit, thick roots) was nevertheless included into broadly understood P. australis (Rahn, 1974). On our trees (Fig. 5C), it almost always separate from the other P. australis samples. Therefore, we propose here to re-establish this species.

There are many local endemics in sect. Virginica (Hassemer, 2019a). Knud Rahn labeled morphologically unusual samples (MO) collected in the Cuzco area (Peru) as possible new species (Fig. 12). These samples are always separate on our trees (Fig. 5C). 


\section{PLANTAGO SUBG. CORONOPUS}

Our trees (Fig. 4, 5B) provide one of the most comprehensive phylogenies for the subg. Coronopus, and are in concordance with the recent work of Höpke et al. (2019). We were able to place those species which have not been the subject of molecular studies. The most interesting are positions of Canarian P. asphodeloides Svent as sister to the rest of species from sect. Coronopus, and $P$.

eocoronopus Pilg. as sister to the rest of the sect. Maritima. The latter species is the rare Afghan plant, practically absent in collections. Pilger (1937) guessed this species to be ancestral for the section, and now we can support this view on the base of both molecules and morphology (Shipunov, 2000a). All our "P. schrenkii" C. Koch samples from the Arctic are identical to P. maritima (Shipunov, 2015).

\section{PLANTAGO SUBG. PSYLLIUM AND ALLIES}

Generally, this part of our trees (Fig. 4, 5D) is the most congruent with the classification of Rahn (1996). Our data is also congruent with the most complete (until now) sampling of the group (Rønsted et al., 2002) and provides robust support for many sub-groupings, which is reflected in our working classification (Supplement Table 1).

Among other results, we found that likely extinct $P$. johnstonii (Hassemer et al., 2018a) branches close to the coastal annual P. limensis and therefore belongs not to ser. Brasilienses but to ser. Hispiduleae. It is possible then that the perennial life form of the former species is the result of adaptation to the "Lomas" microclimate.

The most recent review of the sect. Lancifolia (Hassemer, 2019b) is in agreement with our results but also provides new insights for the classification of this Mediterranean taxon. More research is needed to understand the relations of rare endemic species in this group. 


\section{MORPHOLOGICAL AND COMBINED ANALYSES}

With the Procrustes analysis (Fig. 6), we found that the overall "picture of diversity" is retained between morphological and molecular approaches. In other words, the correspondence between these analyses is high and allows us to run the combined analyses. These analyses, in turn, allow for the $k$ nearest neighbor (Fig. 7) placement of several species which might be otherwise incertae sedis in our working classification (Table 1, Supplement Table 1).

Morphometric characters that reflect general bio-morphological features of species should be assistive in identification. Our analysis provided several insights into this field. We found several repetitive morphometric patterns, "refrains" (Meyen, 1987) within sections and subgenera (Fig. 8); this is additional evidence that morphometric characters should work better within sections (Höpke et al., 2019). We also found several morphological and morphometric characters most correlated with molecular phylogenies (Fig. 9). The morphometric characters are especially interesting because the analysis was performed on the same samples and not on higher units like species descriptions. Most notable is the importance of the presence of taproot, which is another argument for collecting plantains always with carefully preserved underground parts. Among the binary morphological characters, attention should be paid on the research of seed surface characters (Shipunov, 1998b), highly correlated with molecular data (Fig. 9C).

Producing of identification keys is a complicated task in plantains. These keys must take into account the high variability and overlapping of the most distinctive characters used in Plantago taxonomy (Hassemer et al., 2019). Therefore, it might be desirable to employ here results of machine learning techniques such as recursive partitioning. Our partitioning trees (Fig. 10A-B) allow the distinguishing with minimal possible errors on the base of the few most informative characters. As the identification power of trees was relatively high, we decided to provide the dichotomous key for sections based on three runs of classification tree with binary characters and one run with morphometric characters. This 
prototypic key might serve as a framework for the future development of comprehensive keys for the whole group:

1. Ovary with 1-3 ovules and a rudiment of an upper compartment on the adaxial side of the placenta. Corolla lobes longer than $1 \mathrm{~mm}$. Flowers are mostly cleistogamous; corolla lobes form a beak ... sect.

\section{Virginica}

- Ovary structured otherwise. Corolla lobes short or long. Flowers are mostly chasmogamous, corolla in most (but not all) species does not form a beak ... 2 .

2. Non-glandular hairs with joints are strongly refracting, walls between cells oblique. Hairs on leaves narrow, less than $0.04 \mathrm{~mm}$... sect. Gnaphaloides

- Strongly refracting joints absent. Hairs on leaves (if present) variable ... 3.

3. The inner side of the seed is deeply concave ... 13 .

- The inner side of the seed is not deeply concave ... 4 .

4. Ovary with a third compartment at the top on the adaxial side of the placenta, or with a rudiment of it, seen as a thickening at the apex on the posterior side of the ripe placenta. If this compartment absent, then there are few flowers in the inflorescence; no adventitious roots and seeds are longer than $2 \mathrm{~mm}$. Sepals are glabrous on the back ... sect. Mesembrynia

- Ovary without the third compartment, other character combinations are different ... 5.

5. Less than four flowers per inflorescence. Carpophore present ... sect. Carpophorae

- Inflorescence with more than 12 flowers. Carpophore absent ... 6.

6. Posterior sepals with the membranaceous, very conspicuous wing on the back. Leaves are usually remaining green on drying. Corolla tube hairy. Annuals; leaves are often dentate or even dissected ... sect. Coronopus 
- Posterior sepals without a conspicuous wing on the back. Leaves dry differently. Corolla tube hairy or glabrous. Annuals or perennials; leaves with the whole margin or sometimes dentate ... 7 .

7. Annuals. Anthers usually less than $0.5 \mathrm{~mm}$ long ... sect. Micropsyllium

- Perennials. Anthers are longer than $0.5 \mathrm{~mm} \ldots 8$.

8. Ovary hairy. Corolla tube hairy. Leaves usually do not remain green on drying ... sect. Maritima

- Ovary glabrous. Corolla tube glabrous. Leaves usually remain green on drying ... 9.

9. Anthers white both when fresh and dried ... 10 .

- Anthers not white ... 11.

10. Root system mostly of primary and secondary roots. ... sect. Lamprosantha

- Root system mostly of adventitious roots ... sect. Eremopsyllium

11. Corolla lobes longer than $1.5 \mathrm{~mm}$. Ovary with four or fewer ovules. Leaf width usually less than 25 $\mathrm{mm}$... sect. Pacifica

- Corolla lobes shorter than $1.5 \mathrm{~mm}$. Ovary usually with four or more ovules. Leaf width more than 25 $\mathrm{mm} \ldots 12$...

12. Anterior sepals distinctly narrower than posterior, and differently shaped ... sect. Leptostachys

- Anterior and posterior sepals similar ... sect. Plantago

13. Leaves opposite or in whorls of three ... 14.

- Leaves alternate ... 15.

14. Perennials, typically without long glandular hairs. Inner bracts narrow. Seeds longer than $3 \mathrm{~mm}$... sect. Arborescens

- Annuals, with long glandular hairs. Inner bracts are broad. Seeds shorter than $3 \mathrm{~mm}$... sect. Psyllium 
15. Bract with the upper part scarious, acuminate. Some species with anterior sepals united for more than half of their length ... sect. Lancifolia

- Bract without scarious, acuminate upper part. Anterior sepals always free ... 16.

17. Connective of anther very large, about as long as the pollen sacs. Plants densely hairy (leaf surface hardly visible), cells of non-glandular hairs jointed by a common wall with crown-like elongations ... sect. Hymenopsyllium

- Connective of anther smaller. Plants are not densely hairy, cells of hairs without crown-shape elongations ... 18.

18. The nerve of anterior sepals well developed. Corolla lobes are slightly hairy on the back. The concave inner side of the seed covered by a ragged, white membrane, except for two areas to the right and left of the center. Leaves are usually remaining green on drying ... sect. Albicans

- The nerve of anterior sepals present at base only, distal part scarious. Corolla lobes not hairy. White membrane on seeds absent. Leaves usually darken on drying. ... sect. Montana

\section{ACKNOWLEDGMENTS}

We are grateful to the curators of B, BO, BRIT, C, CAS, COL, CONC, F, HUH, IBSC, JBB, KW, LE, M, MA, MHA, MO, MW, NBG/SAM, NY, PE, PRE, SGO, SP, SPF, TI, TNS, UC/JEPS, US, USM herbarium collections (Thiers, 2019) for the permission to work with their herbarium material, and to Barcoding of Life Consortium and personally to Maria L. Kuzmina (University of Guelph, Guelph, Ontario, Canada) for the help with sequencing North American species of Plantago. Our special thanks to Polina Volkova, Jim Keesling and Gabor Sramkó for the help with Plantago samples, and Ekaterina Shipunova and the staff of the Subdirección Científica, Jardín Botánico de Bogotá José Celestino Mutis (Bogotá, Colombia) for the help with Aragoa samples. We thank the Department of Biology of Minot 
State University for the financial support, and Minot State University students for the help with morphometric observations. From May 2014, this research was supported by North Dakota INBRE.

\section{REFERENCES}

Ashkenazy H, Sela I, Levy Karin E, Landan G, Pupko T. 2018. Multiple sequence alignment averaging improves phylogeny reconstruction. Systematic Biology 68: 117-130.

Balbuena JA, Míguez-Lozano R, Blasco-Costa I. 2013. PACo: a novel procrustes application to cophylogenetic analysis. PloS ONE 8: e61048.

Barnéoud, F-M. 1845. Monographie Générale de la Famille des Plantaginées. Paris: Fortin, Masson et Cie.

Bello MA, Chase MW, Olmstead RG, Rønsted NAH, Albach D. 2002. The páramo endemic Aragoa is the sister genus of Plantago (Plantaginaceae; Lamiales): evidence from plastid $r b c \mathrm{~L}$ and nuclear ribosomal ITS sequence data. Kew Bulletin 57: 585-597.

Bello MA, Rudall PJ, González F, Fernández AJL. 2004. Floral morphology and development in Aragoa (Plantaginaceae) and related members of the order Lamiales. International Journal of Plant Sciences 165: 723-738.

Bergius PJ. 1768. Littorella juncea, en svensk växt. Kongliga Vetenskaps Academiens Handlingar 29: $337-344$.

Carlquist, S. 1970. Wood anatomy of insular species of Plantago and the problem of raylessness. Bulletin of the Torrey Botanical Club 97: 353-361.

Cho Y, Mower JP, Qiu YL, Palmer JD. 2004. Mitochondrial substitution rates are extraordinarily elevated and variable in a genus of flowering plants. Proceedings of the National Academy of Sciences 
of the United States of America 101: 17741-17746.

Choi J, Lee HJ, Shipunov A. 2015. All that is gold does not glitter? Age, taxonomy, and ancient plant DNA quality. PeerJ 3: e1087.

Decaisne J. 1852. Plantaginaceae Sect. 1 Candolle A. de. Prodromus Systematis Naturalis Regni Vegetabilis 13: 693-737.

Di Pietro R, Iamonico D, Soldano A. 2013. Proposal to conserve the name Plantago serpentina against $P$. strictissima (Plantaginaceae). Taxon 62: 635-637.

Doweld, A.B., and A. Shipunov. 2017. Proposal to reject the name Plantago indica (Plantaginaceae). Taxon. 66: 205-206.

Dumortier B-C. 1829. Analyse des familles des plantes: avec l'indication des principaux genres qui s'y rattachent. Tournay.

Edgar RC. 2004. MUSCLE: multiple sequence alignment with high accuracy and high throughput. Nucleic Acids Research 32: 1792-1797.

Fernández AJL. 1995. Scrophulariaceae - Aragoeae. Flora de Colombia. 16.

Fernández AJL. 1993. Novedades taxonómicas en Aragoa H.B.K. (Scrophulariaceae) y sinopsis del género. Anales del Jardín Botánico de Madrid 51: 73-96.

Fernández AJL. 2002. Algunos patrones de distribución y endemismo en plantas vasculares de los páramos de Colombia. Memorias Congreso Mundial de Páramos, Paipa 1: 213-240.

Funk VA, Edwards R, Sterling K. 2018. The problem with (out) vouchers. Taxon 67: 3-5.

Hassemer G, Rønsted NAH. 2016. Yet another new species from one of the best-studied neotropical areas: Plantago humboldtiana (Plantaginaceae), an extremely narrow endemic new species from a waterfall in southern Brazil. PeerJ 4: e2050. 
Hassemer G. 2018a. Notes on the montane Indo-Iranian species in Plantago subgenus Plantago (Plantaginaceae). Phytotaxa 336: 59-68.

Hassemer G. 2018b. Advances to the taxonomic knowledge of Plantago subulata (Plantago sect. Maritima, Plantaginaceae). Turkish Journal of Botany 42: 653-661.

Hassemer G. 2019a. Novelties and notes on Plantago sect. Virginica (Plantaginaceae), including the description of a new species and a revised identification key. Webbia 74: 29-41.

Hassemer G. 2019b. Mediterranean mysteries: notes on Plantago sect. Lancifolia (Plantaginaceae). Phytotaxa 423: 111-128.

Hassemer G, Bruun-Lund S, Shipunov A, Briggs BG, Meudt HM, Rønsted NAH. 2019. The application of high-throughput sequencing for taxonomy: the case of Plantago subg. Plantago (Plantaginaceae). Molecular Phylogenetics and Evolution 138: 156-173.

Hassemer G, De Giovanni R, Trevisan R. 2016. The use of potential distribution models in the study of the distribution and conservation status of plants: the case of Plantago L. (Plantaginaceae) in Brazil. Journal of the Torrey Botanical Society 143: 38-49.

Hassemer G, Shipunov A, Rønsted NAH, Meudt HM. 2018a. Taxonomic and geographic novelties in the genus Plantago (Plantaginaceae) in Chile, including the description of a new species. Phytotaxa 340: $137-156$.

Heibl C. 2008. IPS: R language tree plotting tools and interfaces to diverse phylogenetic software packages. URL: https://github.com/heibl/ips [last accessed 19 Jun. 2019]

Höpke J, Mucina L, Albach DC. 2019. Phylogenetic and morphometric analysis of Plantago section Coronopus (Plantaginaceae). Taxon 68: 315-339.

Hoggard RK, Kores PJ, Molvray M, Hoggard GD, Broughton DA. 2003. Molecular systematics 
and biogeography of the amphibious genus Littorella (Plantaginaceae). American Journal of Botany 90: $429-435$.

Ishikawa N, Yokoyama J, Tsukaya H. 2009. Molecular evidence of reticulate evolution in the subgenus Plantago (Plantaginaceae). American Journal of Botany 96: 1627-1635.

Ishikawa N, Yokoyama J, Ikeda H, Takabe E, Tsukaya H. 2006. Evaluation of morphological and molecular variation in Plantago asiatica var. densiuscula, with special reference to the systematic treatment of Plantago asiatica var. yakusimensis. Journal of Plant Research 119: 385-395.

\section{Iwanycki Ahlstrand NE, Verstraete B, Hassemer G, Dunbar-Co S, Hoggard R, Meudt HM,}

Rønsted NAH. 2019. Ancestral range reconstruction of remote oceanic island species of Plantago

(Plantaginaceae) reveals differing scales and modes of dispersal. Journal of Biogeography 46: 706-722.

Kunth KS. 1818. Nova Genera et Species Plantarum. 3. Paris.

Kuzmina M, Ivanova N. 2011. Primer sets for plants and fungi. URL: http://ccdb.ca/site/wpcontent/uploads/2016/09/CCDB_PrimerSets-Plants.pdf [last accessed 19 Jun. 2019].

Larsson A. 2014. AliView: a fast and lightweight alignment viewer and editor for large data sets.

Bioinformatics 30: 3276-3278.

Li Z, Wei L, Hoggard RK. 2011. Plantaginaceae. In: Wu Z, Raven PH, Hong D, eds. Flora of China, Vol. 19, 495-503. Beijing: Science Press, and St. Louis: Missouri Botanical Garden Press.

Linnaeus C. 1753. Species Plantarum, 112-116. Holmiae.

Linnaeus C. 1754. Genera Plantarum, 136. Holmiae.

Matsuo K. 1989. Biosystematic studies on the genus Plantago. 1. Variations in Plantago japonica and its related species with special reference to its identity. Acta Phytotaxonomica et Geobotanica 40: $37-$ 60. 
Meudt HM. 2011. Amplified fragment length polymorphism data reveal a history of auto-and allopolyploidy in New Zealand endemic species of Plantago (Plantaginaceae): new perspectives on a taxonomically challenging group. International Journal of Plant Sciences 172: 220-237.

Meudt HM. 2012. A taxonomic revision of native New Zealand Plantago (Plantaginaceae). New Zealand Journal of Botany 50: 101-178.

Meudt HM, Rojas-Andrés BM, Prebble JM, Low E, Garnock-Jones PJ, Albach DC. 2015. Is genome downsizing associated with diversification in polyploid lineages of Veronica? Botanical Journal of the Linnean Society 178: 243-266.

Meyen SV. 1987. Fundamentals of Palaeobotany. London: Chapman and Hall.

Morgan-Richards M, Wolff K. 1999. Genetic structure and differentiation of Plantago major reveals a pair of sympatric sister species. Molecular Ecology 8: 1027-1036.

Nixon K. 1999. The parsimony ratchet, a new method for rapid parsimony analysis. Cladistics 15: 407-414.

Paradis E, Claude J, Strimmer K. 2004. APE: analyses of phylogenetics and evolution in R language. Bioinformatics 20: 289-290.

Peres-Neto PR, Jackson DA. 2001. How well do multivariate data sets match? The advantages of a Procrustean superimposition approach over the Mantel test. Oecologia 129: 169-178.

Pilger R. 1937. Plantaginaceae. In: Engler A, ed. Das Pflanzenreich, IV 269 (102, heft). Leipzig: Wilhelm Engelmann.

Palermo AM, De Vita A, Peruzzi L, Gargano D, Bernardo L, Musacchio A. 2010. Does Plantago brutia Ten. (Plantaginaceae) merit specific rank? Insights from nrDNA and cpDNA data. Plant Biosystems 144: 573-581. 
Preston JC, Ciera CM, Hileman LC. 2011. Gradual disintegration of the floral symmetry gene network is implicated in the evolution of a wind-pollination syndrome. Proceedings of the National Academy of Sciences of the United States of America 108: 2343-2348.

R Core Team. 2019. R: A language and environment for statistical computing. R Foundation for Statistical Computing, Vienna, Austria. URL: http://www.R-project.org/ [last accessed 19 Jun. 2019].

Rahn K. 1974. Plantago section Virginica; a taxonomic revision of a group of American plantains, using experimental, taximetric and classical methods. Dansk Botanisk Arkiv 30: 1-180.

Rahn K. 1996. A phylogenetic study of the Plantaginaceae. Botanical Journal of the Linnean Society 120: $145-198$.

Reveal JL. 2011. Indices nominum supragenericorum plantarum vascularium. Alphabetical listing by genera of validly published suprageneric names. URL:

http://www.plantsystematics.org/reveal/pbio/fam/allspgnames.html [last accessed 19 Jun. 2019]

Ripley BD. 1996. Pattern Recognition and Neural Networks. Cambridge: Cambridge University Press.

Ronquist F, Huelsenbeck JP. 2003. MrBayes 3: Bayesian phylogenetic inference under mixed models. Bioinformatics 19: 1572-1574.

Rønsted NAH, Chase MW, Albach DC, Bello MA. 2002. Phylogenetic relationships within Plantago (Plantaginaceae): evidence from nuclear ribosomal ITS and plastid trnL-F sequence data. Botanical Journal of the Linnean Society 139: 323-338.

Samarakoon T, Wang SY, Alford MH. 2013. Enhancing PCR amplification of DNA from recalcitrant plant specimens using a trehalose-based additive. Applications in Plant Sciences 1: 1200236.

Schliep KP. 2011. phangorn: phylogenetic analysis in R. Bioinformatics 27: 592-593. 
Seifert KA, Crous PW, Frisvad JC. 2008. Correcting the impact factors of taxonomic journals by appropriate citation of taxonomy (ACT). Persoonia 20: 105.

Shehata AA, Loutfy MHA. 2006. On the taxonomy of Plantaginaceae Juss. sensu lato: evidence from SEM of the seed coat. Turkish Journal of Botany 30: 71-84.

Shipunov A. 1998a. Plantains (genera Plantago L. and Psyllium Mill.) from European Russia and adjacent territories. Ph.D. thesis. Moscow State University, Moscow, Russia.

Shipunov A. 1998b. The significance of the sculpture of the surface of seeds for systematics of genera Plantago L. and Psyllium Mill. (Plantaginaceae). Bulletin of Moscow Society of Naturalists. Biol. Series 103: 41-51.

Shipunov A. 2000a. On the taxonomic status of Plantago eocoronopus Pilger and P. arachnoidea Schrenk var. lorata Liu. Bulletin of Moscow Society of Naturalists. Biol. Series 105: 60-64.

Shipunov A. 2000b. The genera Plantago L. and Psyllium Mill. (Plantaginaceae Juss.) in the flora of East Europe. Novitates Systematicae Plantarum Vascularium 32: 139-152.

Shipunov A. 2015. Plantago schrenkii is $P$. maritima: morphological and molecular evidence. Annales Botanici Fennici 52: 33-37.

Shipunov A. 2017. Portion of Plantaginaceae, the Plantain Family: Littorella and Plantago. Online edition. In: Naczi RFC, Abbott JR, eds. New Manual of Vascular Plants of Northeastern United States and Adjacent Canada. New York: NYBG Press.

Shipunov A. 2019a. Plantago and Littorella. In: Freeman, C and Rabeler R, eds. Flora of North America. Volume XVII, 280-293. New York and Oxford: Oxford University Press.

Shipunov A. 2019b. shipunov: Miscellaneous Functions from Alexey Shipunov. R package version 1.2. URL: https://CRAN.R-project.org/package=shipunov [last accessed 19 Jun. 2019] 
Stuessy TF, Crawford DJ, López-Sepúlveda P [eds.] 2017. Plants of oceanic islands: evolution, biogeography, and conservation of the flora of the Juan Fernández (Robinson Crusoe) Archipelago. Cambridge: Cambridge University Press.

Tay ML, Meudt HM, Garnock-Jones PJ, Ritchie PA. 2010. DNA sequences from three genomes reveal multiple long-distance dispersals and non-monophyly of sections in Australasian Plantago (Plantaginaceae). Australian Systematic Botany 23: 47-68.

Therneau T, Atkinson B, Ripley BD. 2014. rpart: Recursive Partitioning and Regression Trees. R package version 4.1-8. URL: http://CRAN.R-project.org/package=rpart [last accessed 19 Jun. 2019]

Thiers B. 2019. Index Herbariorum: a global directory of public herbaria and associated staff. New York Botanical Garden's Virtual Herbarium. URL: http://sweetgum.nybg.org/science/ih [last accessed 19 Jun. 2019]

Tsinger N. 1905. Plantago tenuiflora W.K. and Plantago minor Fries. (to the question of the climate influence of the plant life and form). Mémoires de la Société des Naturalistes de Kiew. 19: 145-162.

Venables WN, Ripley BD. 2002. Modern Applied Statistics with S. New York: Springer. 


\section{FIGURE LEGENDS}

Figure 1. Phylogeny of the Plantagineae: the general arrangement of clades (genera and subgenera). Each triangle is the result of concatenation applied to the branches of the Bayesian (MB) phylogenetic tree.

Figure 2. The overview of the MB tree based on the "tall" dataset. Branches with support $>90 \%$ thickened.

Figure 3. Density surface of the cophenetic space, based on the MB trees from the "tall" dataset. This surface is the result of multidimensional scaling of the cophenetic distances between tree tips; density of points estimated with 2D binned kernel. "Ridges" reflect areas with the highest density and correspond well with three major subgeneric divisions of Plantago. Note the three-fold structure of the "phylogenetic surface": tallest corresponds with subg. Plantago, close and behind it, is subg. Coronopus whereas subg. Psyllium and allies form the rightmost "ridge."

Figure 4. The phylogeny of Plantagineae obtained from the "broad" dataset (based on MB trees). Stars (*) mark species which have not been barcoded before. Numbers on nodes are Bayesian posterior probabilities $(\%)$.

Figure 5. The phylogeny of Plantagineae obtained from the "tall" dataset (based on MB trees). (A) Aragoa and Littorella (B) Plantago subgenera Coronopus and Plantago (first part); (C) subgenus Plantago (second part); (D) subgenus Psyllium and allies. Stars (*) mark species which have not been barcoded before. Numbers on nodes are Bayesian posterior probabilities (\%).

Figure 6. Scatterplot of the data points from joint molecular and morphological datasets (genus Plantago only) after the Procrustes superimposition. Differences in location of each species designated with arrows. These arrows start from the location defined by molecular data and target to the location defined by morphological data. The angle between solid and dashed axes reflects the overall 
Procrustean distance.

Figure 7. $k$-nearest neighbors $(k$-NN) plane predicts Plantago subgenera from the combined (molecular and morphological) data. The combined data was projected into a 2-dimensional plane. Solid dots correspond to subgenera Plantago (red), Coronopus (black), and Psyllium with allies (green). For each location shown as a semi-transparent dot, subgeneric placement learned with the $k$-NN algorithm, and the dot was colored following this prediction. Now, if any new species appear which corresponds with any of these semi-transparent dots, its subgeneric placement is already predicted.

Figure 8. Plantago leaf shapes vs. subgenus. This plot derived from the cross-tabulation, which uses a morphometric dataset for leaf shapes.

Figure 9. Morphological characters in Plantago: (A) morphometric measurements of seven "spot" characters; (B) "molecular weights" (median and maximum average Spearman correlations on 1000 bootstrap replicates) of morphometric characters; (C) "molecular weights" (average correlations with "tall" tree and combined molecular-morphology tree) of binary characters, character abbreviations explained in the text and Support Table 4.

Figure 10. Recursive partitioning of Plantago sections with morphological characters, the prototype of diagnostic key: (A) first run and (B) second run on binary morphological characters. Character 
bioRxiv preprint doi: https://doi.org/10.1101/2020.07.31.230813; this version posted August 3, 2020. The copyright holder has placed this preprint (which was not certified by peer review) in the Public Domain. It is no longer restricted by copyright. Anyone can legally share, reuse, remix, or adapt this material for any purpose without crediting the original authors.

\section{TABLES}

Table 1. Machine learned placements of the molecularly unsampled species. 


\section{SUPPORT MATERIALS}

Support Table 1. Working classification of Plantagineae.

Support Table 2. Vouchers of Plantagineae samples. Samples used for morphometric measurements

labeled with star* (please note that not all measured samples yielded the DNA of the reliable quality).

Support Table 3. GenBank accession numbers of Plantagineae samples.

Support Table 4. Binary morphological characters used. 


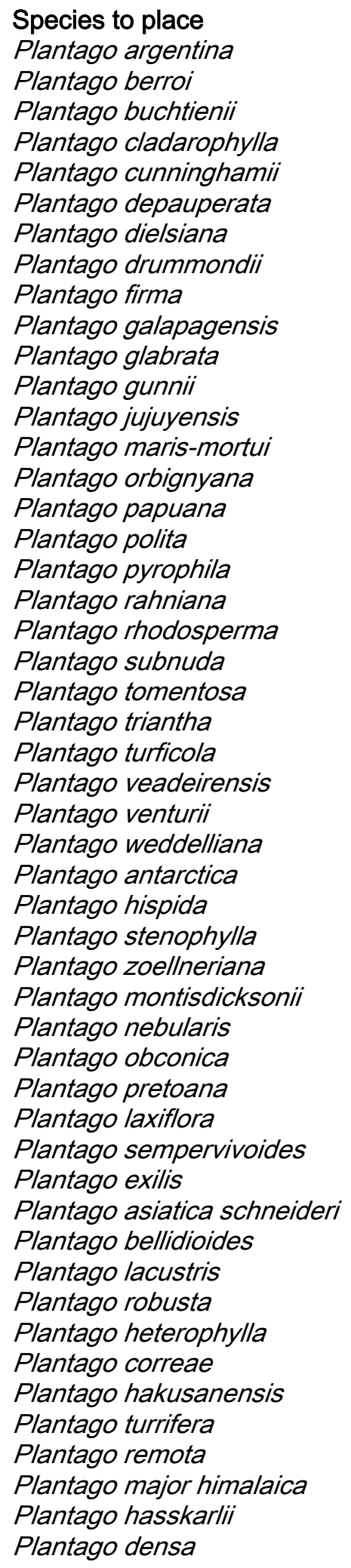

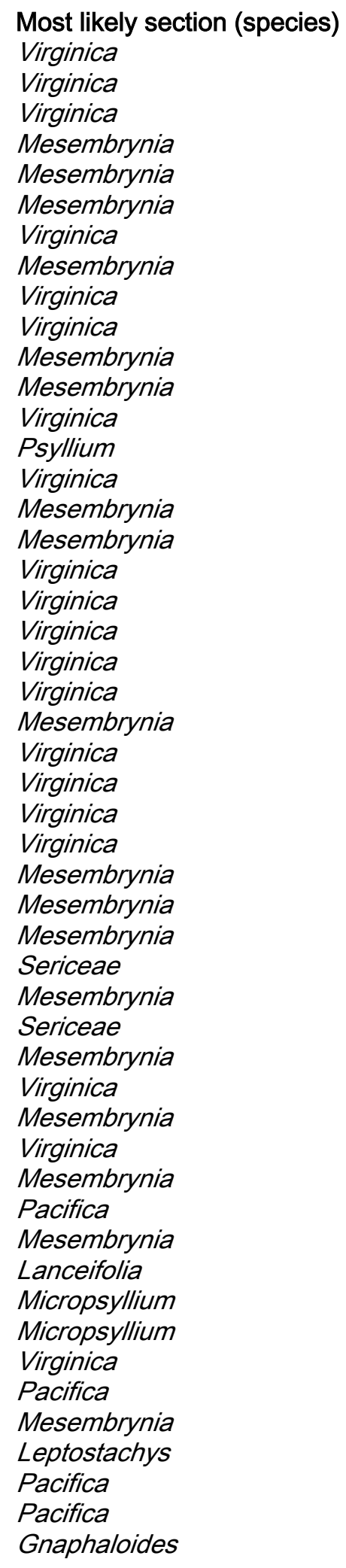

Probability, \% 100 100 100 100 100 100 100 100 100 100 100 100 100 100 100 100 100 100 100 100 100 100 100 100 100 100 100 99 99 99 99 98 98 97 97 93 
bioRxiv preprint doi: https://doi.org/10.1101/2020.07.31.230813; this version posted August 3, 2020. The copyright holder has placed this preprint (which was not certified by peer review) in the Public Domain. It is no longer restricted by copyright. Anyone can legally share, reuse, remix, or adapt this material fler any pyrpose without crediting the original authors.

Plantago aundensis

Plantago akkensis

Plantago orzuiensis

Plantago anatolica

Plantago trichophora

Plantago baltistanica

Plantago cyrenaica

Plantago tatarica

Plantago multiscapa

Plantago pentasperma

Plantago sharifii

Plantago benisnassenii

Aragoa funckii

Aragoa hammenii

Aragoa tamana
Pacifica

71

Ciliatae $\quad 70$

$\begin{array}{ll}\text { Ciliatae } & 67\end{array}$

Pacifica $\quad 64$

Mesembrynia 60

Montana $\quad 50$

Minutae $\quad 50$

$\begin{array}{ll}\text { Pacifica } & 50\end{array}$

Mesembrynia $\quad 49$

Mesembrynia $\quad 47$

Albicantes $\quad 46$

Hispiduleae $\quad 41$

Aragoa kogiorum 15

Aragoa lycopodioides $\quad 15$

Aragoa lycopodioides 16 
bioRxiv preprint doi: https://doi.org/10.1101/2020.07.31.230813; this version posted August 3, 2020. The copyright holder has placed this preprint (which was not certified by peer review) in the Public Domain. It is no longer restricted by copyright. Anyone can legally share, reuse, remix, or adapt this material_forany purposemithout_crediting the original authors.

Second likely section (species)

Pacifica

Pacifica

Carpophorae

Gnaphaloides

Virginica

Brasilienses

Pacifica

Lamprosantha

Eremopsyllium

Carpophorae

Pacifica

Plantago

Pacifica

Sericeae

Mesembrynia

Pacifica

Pacifica

Plantago

Pacifica

Virginica

Plantago

Plantago

Brasilienses
Probability, \% Third likely section (species)

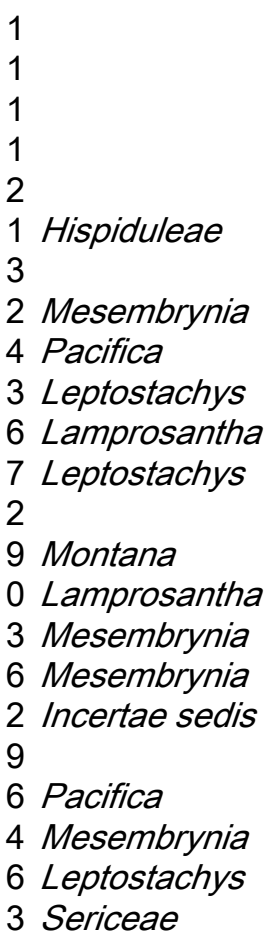

Page 3 
bioRxiv preprint doi: https://doi.org/10.1101/2020.07.31.230813; this version posted August 3, 2020. The copyright holder has placed this preprint (which was not certified by peer review) in the Public Domain. It is no longer restricted by copyright. Anyone can legally share, reuse, remix, or adapt this material for any pyrpose without crediting the original authors.

Mesembrynia

Albicantes

Albicantes

Eremopsyllium

Pacifica

Micropsyllium

Hymenopsyllium

Plantago

Micropsyllium

Virginica

Ciliatae

Ciliatae

Aragoa lucidula

Aragoa cundinamarcensis

Aragoa cundinamarcensis

\section{9}

23 Minutae

21 Bauphula

19 Mesembrynia

39 Leptostachys

40 Bougueria

25 Ciliatae

32 Mesembrynia

30 Pacifica

40 Lamprosantha

28 Minutae

26 Hymenopsyllium

15 Aragoa lycopodioides

15 Aragoa abscondita

15 Aragoa parviflora 
bioRxiv preprint doi: https://doi.org/10.1101/2020.07.31.230813; this version posted August 3, 2020. The copyright holder has placed this preprint (which was not certified by peer review) in the Public Domain. It is no longer restricted by copyright. Anyone can legally share, reuse, remix, or adapt this material for any purpose without arediting the original authors.

\section{Probability, \%}


bioRxiv preprint doi: https://doi.org/10.1101/2020.07.31.230813; this version posted August 3, 2020. The copyright holder has placed this preprint (which was not certified by peer review) in the Public Domain. It is no longer restricted by copyright. Anyone can legally share, reuse, remix, or adapt this material for any pyrpose without crediting the original authors. 


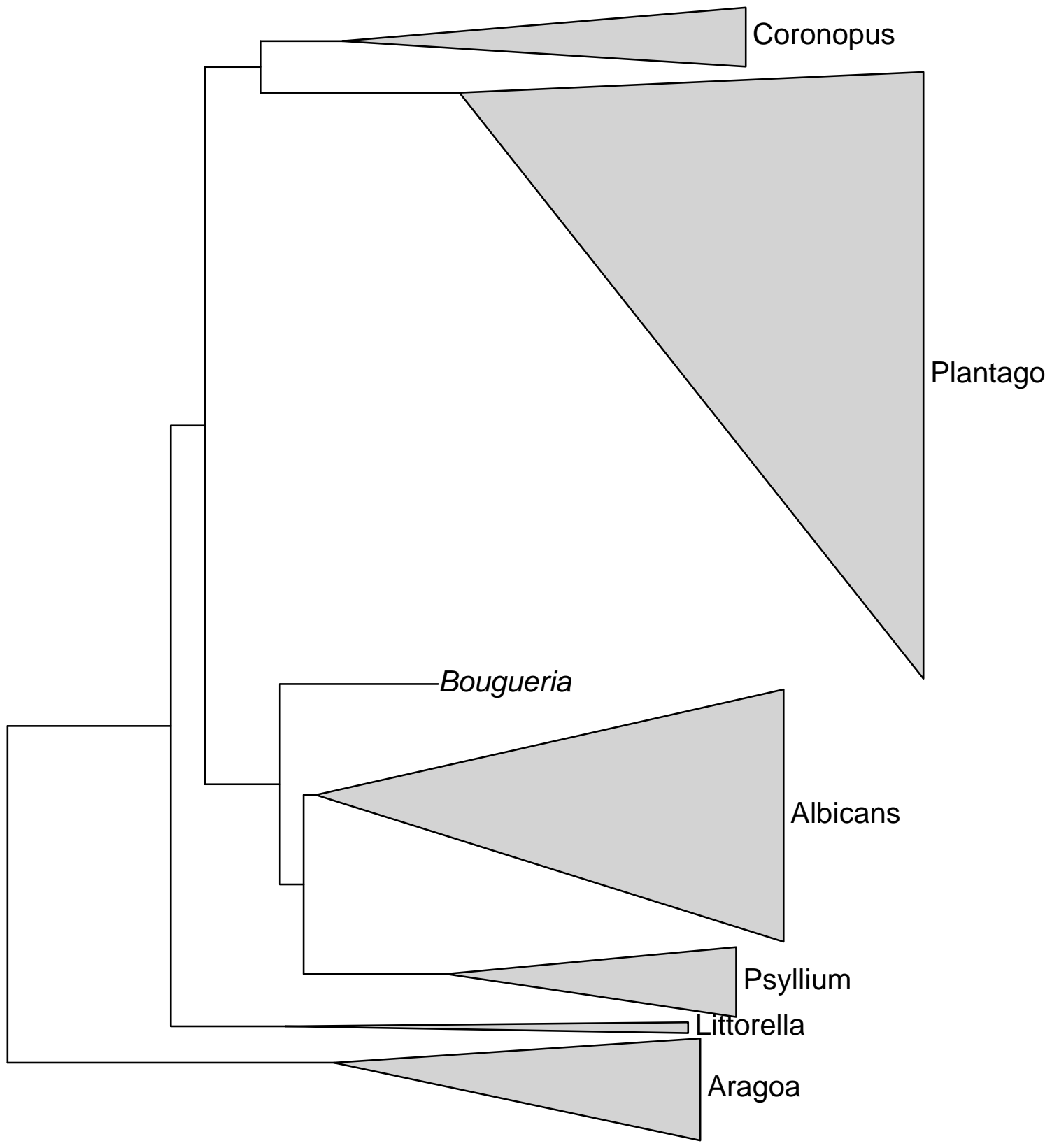




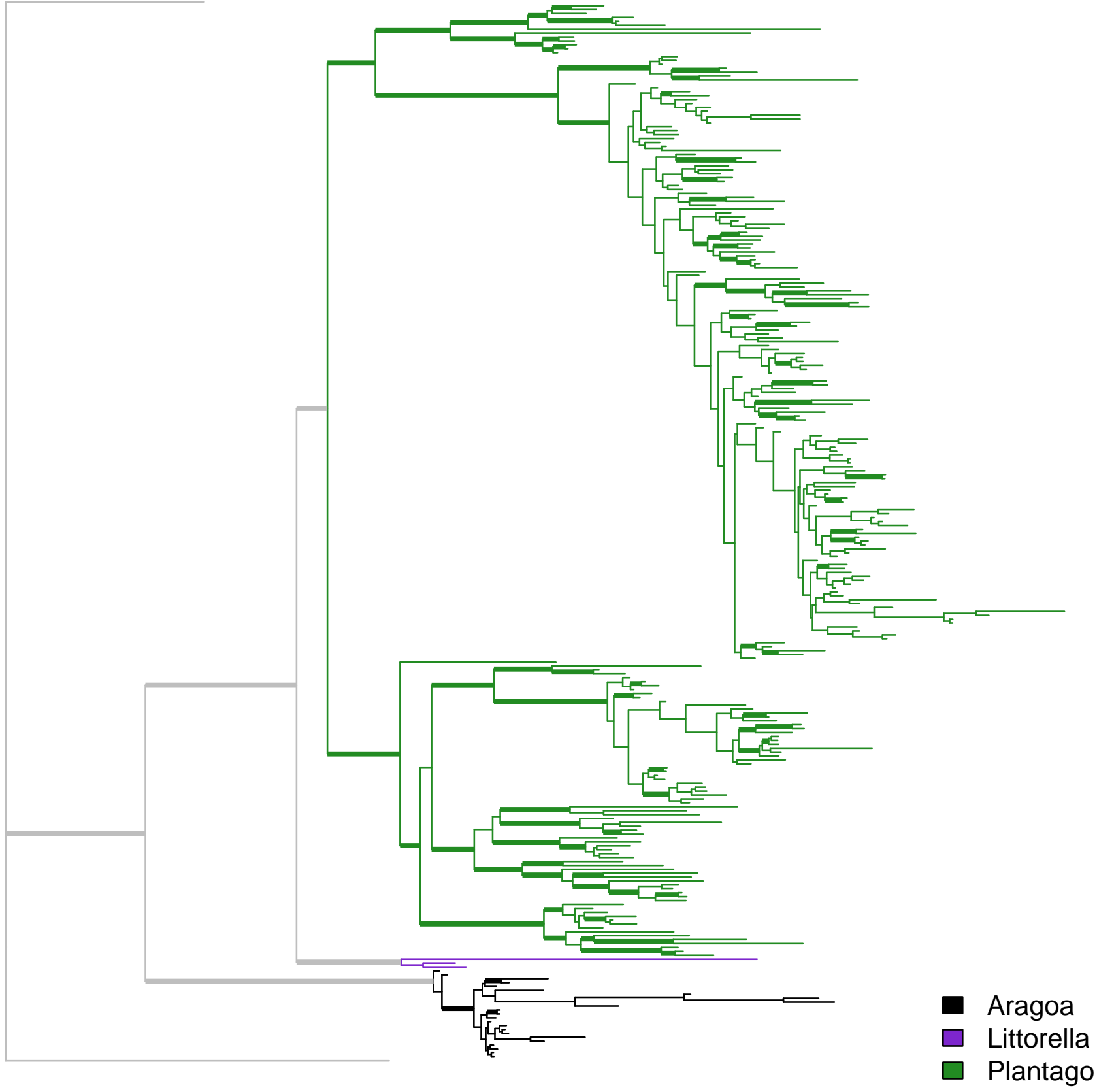





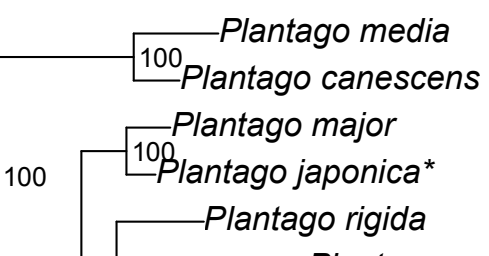

bioRxiv preprint doi https://doi.org/10.1101/202001.31.2308131 Plantago sparsiflora preprint (which was not certified by peer review) in the Public Domaiklatrisagodortugehèstricted by copyright. Anyone can legally share, reuse, remix, or adapt this material for anypurpgse without frediting the original authors.
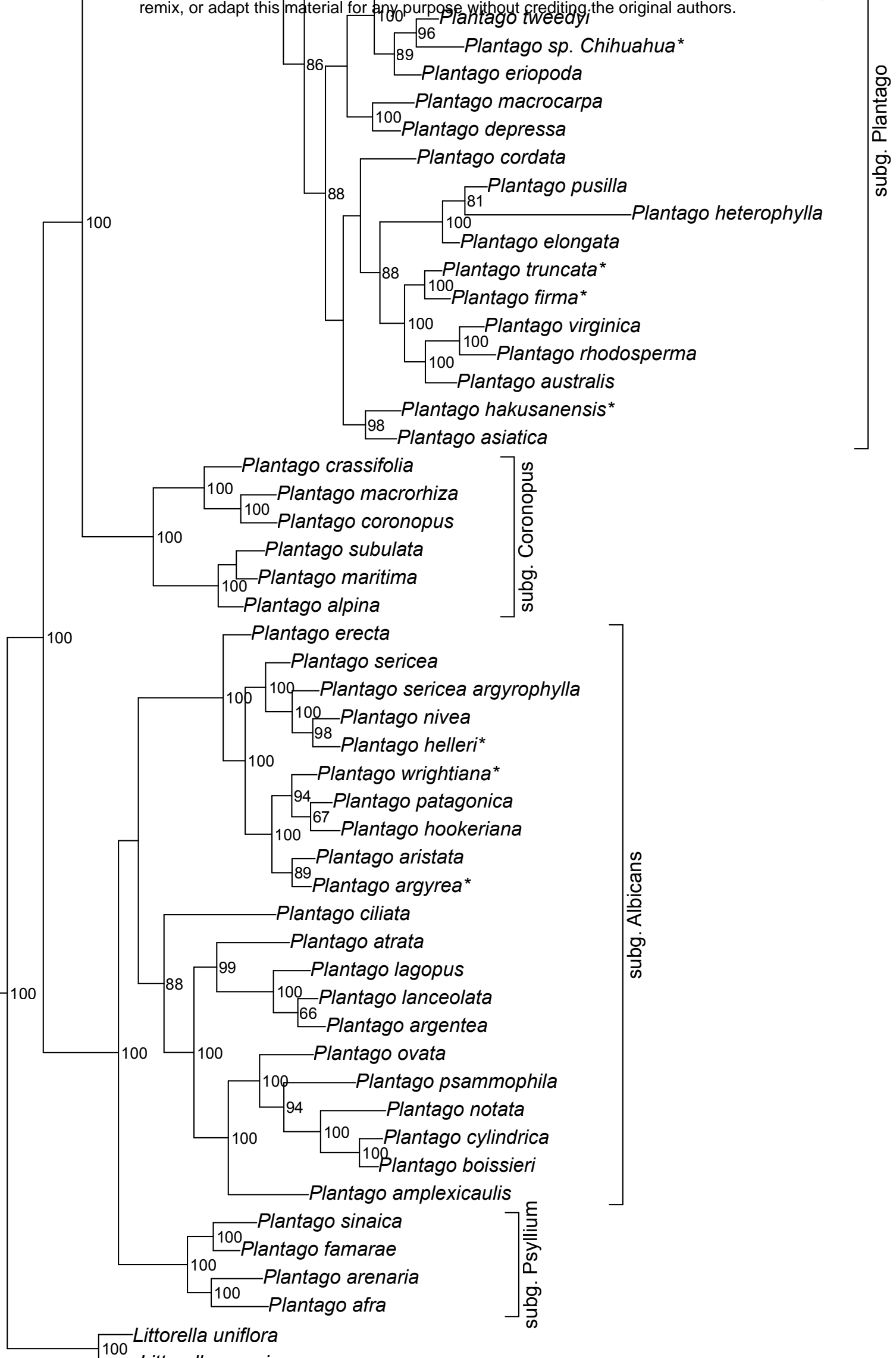

100 Littorella uniflora

Aragoa lucidula*

100 Aragoa cleefii

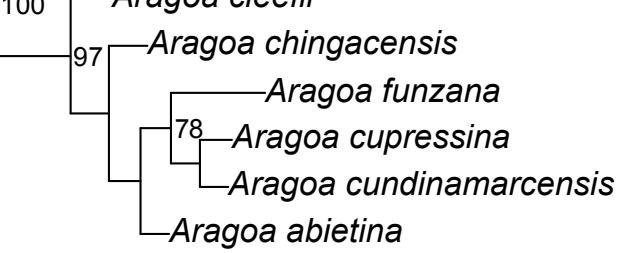


Subgg. Bougueria, Psyllium and allies

100

[Aragoa lucidula*

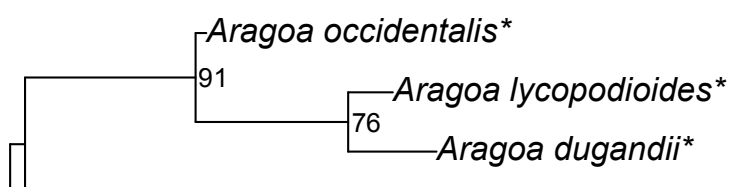

- Littorella uniflora

00

Littorella australis

Littorella americana

Aragoa diazii *

96 Aragoa romeroi*

Aragoa perez-arbelaeziana*

Aragoa cleefii

Aragoa castroviejoi*

1oAragoa chingacensis

Aragoa jaramilloi*

Aragoa cupressina

Aragoa cundinamarcensis

Aragoa corrugatifolia

Aragoa funzana

76

Aragoa abscondita*

Aragoa parviflora*

Aragoa kogiorum*

Aragoa picachensis* 


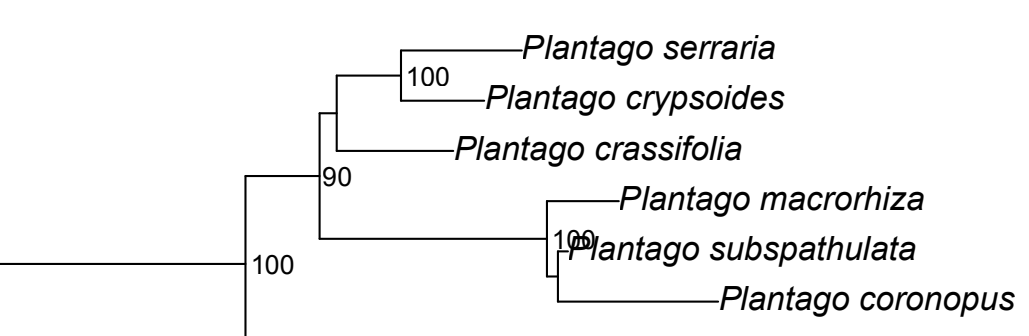

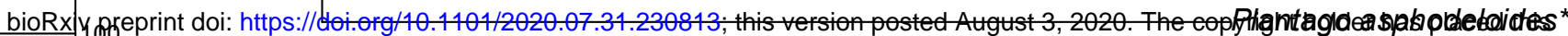
preprint (Which was not certified by peer review) in the Public Domain. It is no longer restricted by copyright. Anyone ${ }_{*}$ can legally share, reuse,

88 Plantago unibracteata

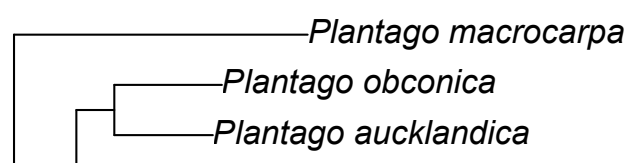

Plantago rupicola

CPlantago sp. Hupeh1*

$94 \quad$ Plantago depressa
$76 \quad$ Plantago komarovii
76 Plantago camtschatica

${ }_{98}$ Plantago tweedyi

100 Plantago sp. Chihuahua

Plantago eriopoda

$100 \sqrt{100}$ Plantago sparsiflora

Plantago rugelii

Plantago rapensis

96Plantago hawaiensis

Plantago aundensis*

Plantago turrifera*
Plantago stauntonii
Plantago euana

Plantago drummondii*

Plantago laxiflora*

Plantago cunninghamii

Plantago cladarophylla
$\begin{aligned} & \text { Plantago raoulii } \\ & 82\end{aligned}$
Plantago hedleyi

Plantago antarctica*

Plantago muelleri

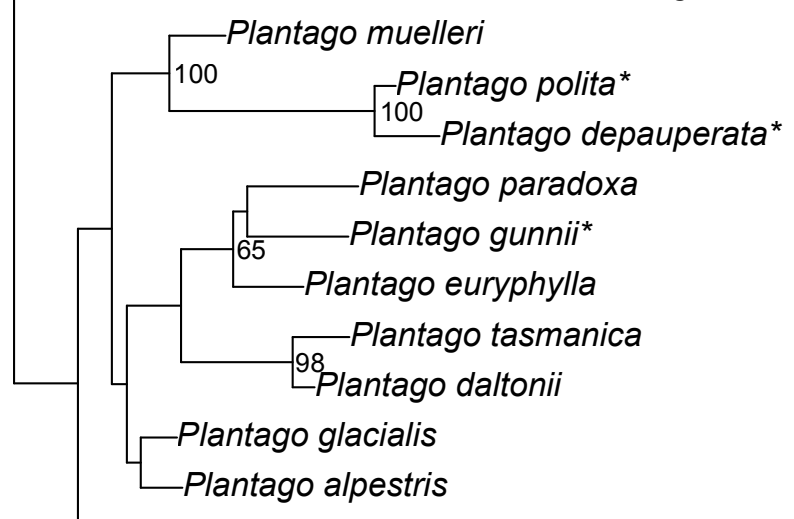


-Plantago reniformis

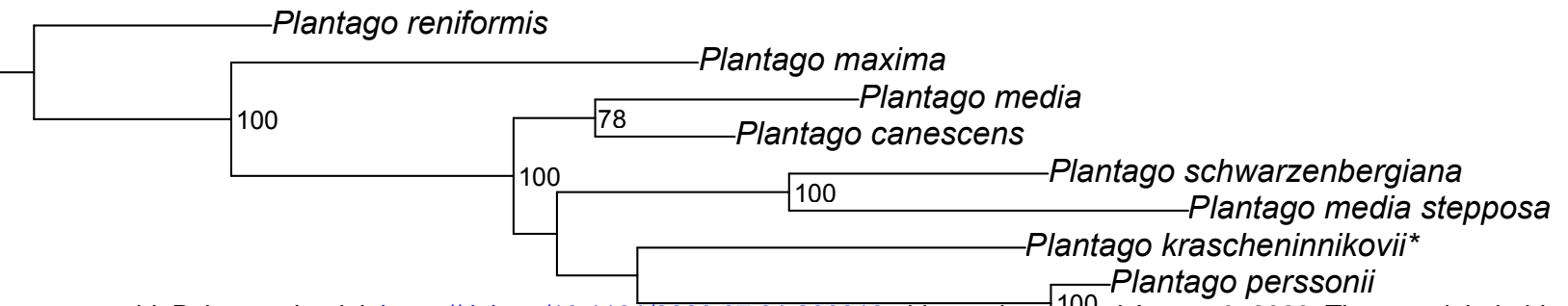

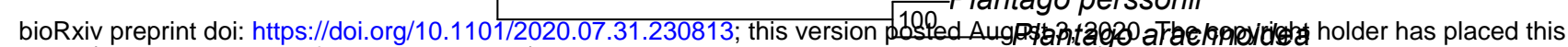
preprint (which was not certified by peer review) in the Public Domain. Dt is no longer restricted,by copyright. Anyone can legally share, reuse, remix, or adapt this material for any purposeth

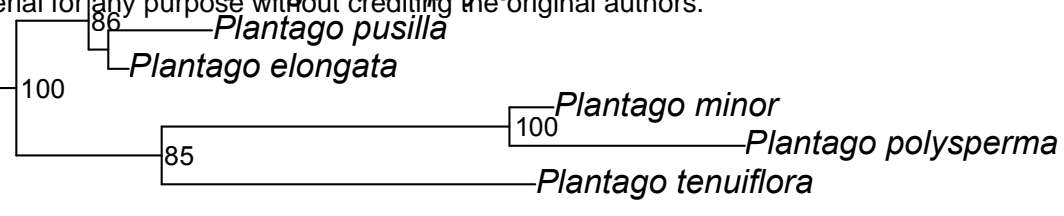

Plantago fischeri

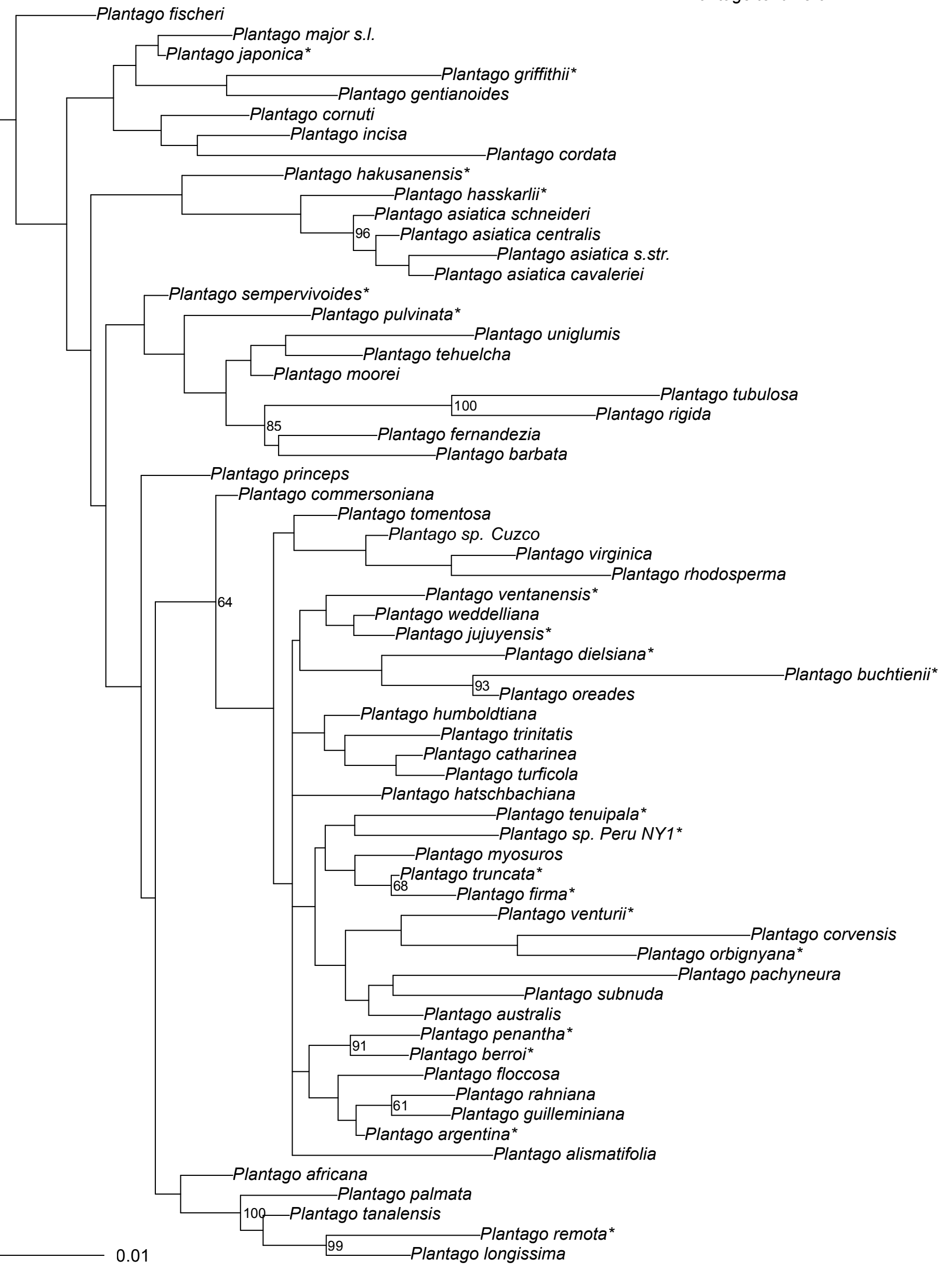




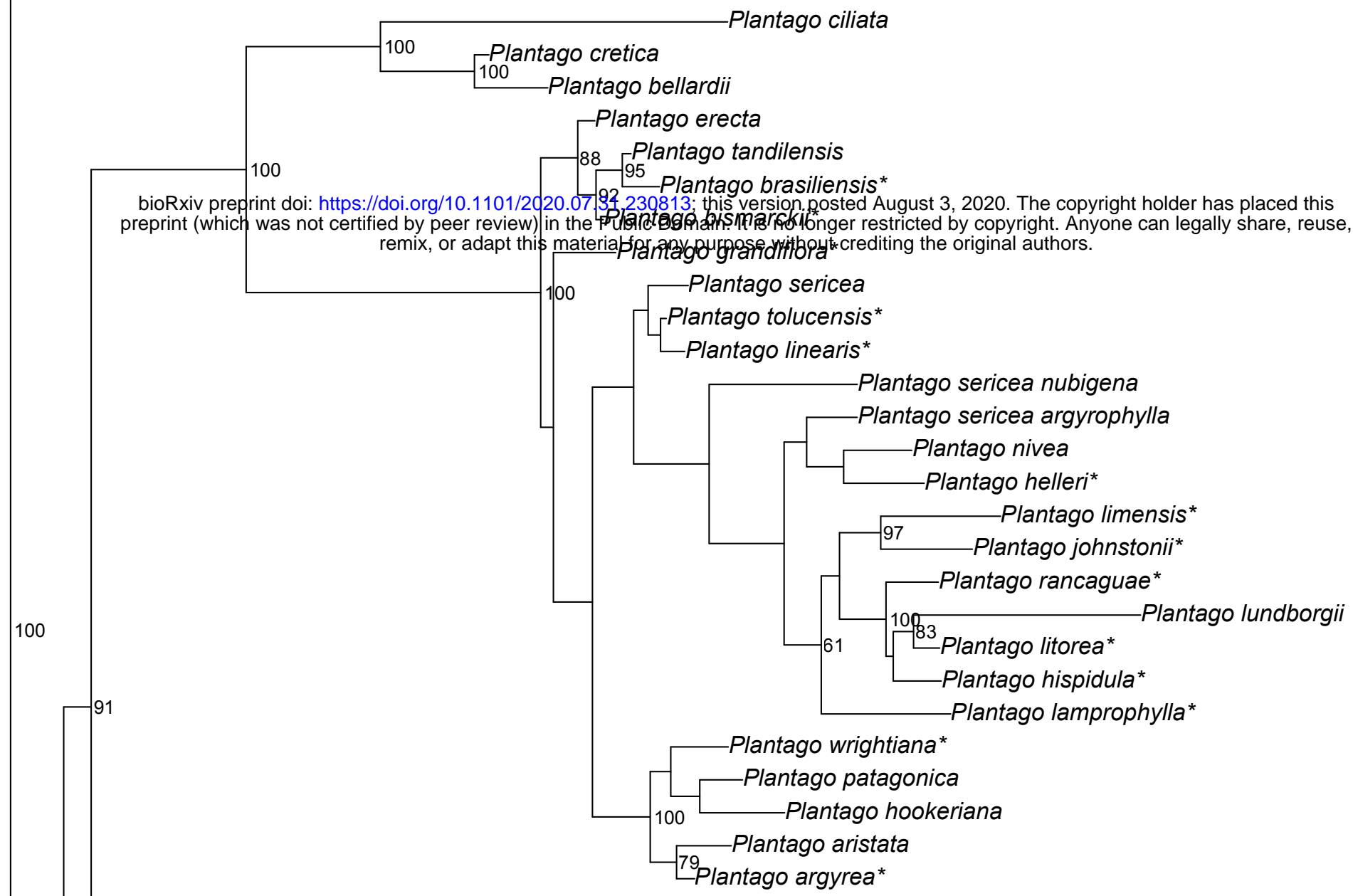

Plantago lagocephala*

$100-63 \quad$ Plantago minuta

Plantago lachnantha*

100

Plantago nivalis

80 Plantago monosperma*

100 Plantago atrata

Plantago lagopus

$100 \quad$ Plantago loeflingii ${ }^{*}$

Plantago leiopetala

100

L Plantago lanceolata

62 Plantago argentea

Plantago altissima*

Plantago stocksii

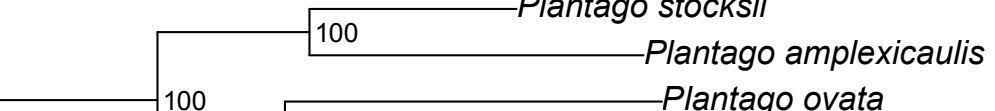

$100 \quad$ Plantago ovata

$190 \quad 94 \quad$ Plantago psammophila

$62 \quad$ Plantago notata

$100-93$ Plantago cylindrica

Plantago boissieri

87 Plantago tunetana*

Plantago sinaica

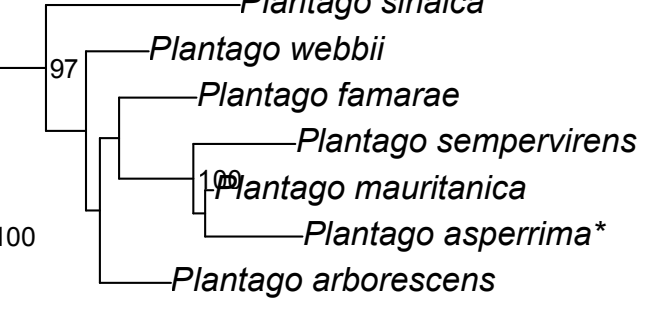

Plantago arenaria

-Plantago euphratica*

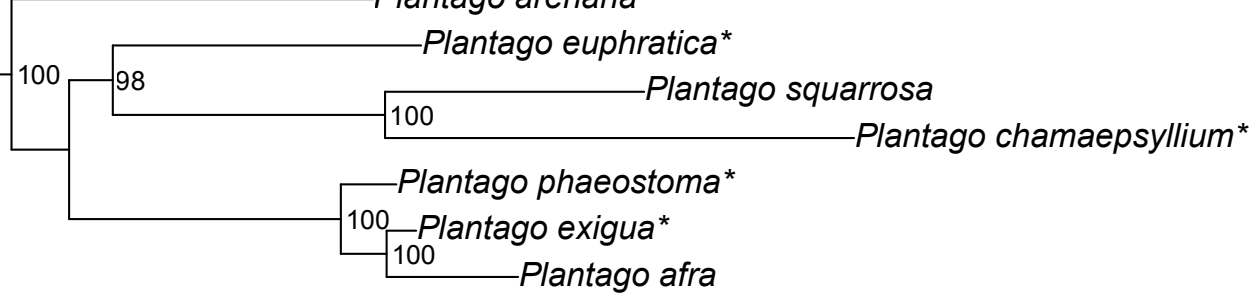




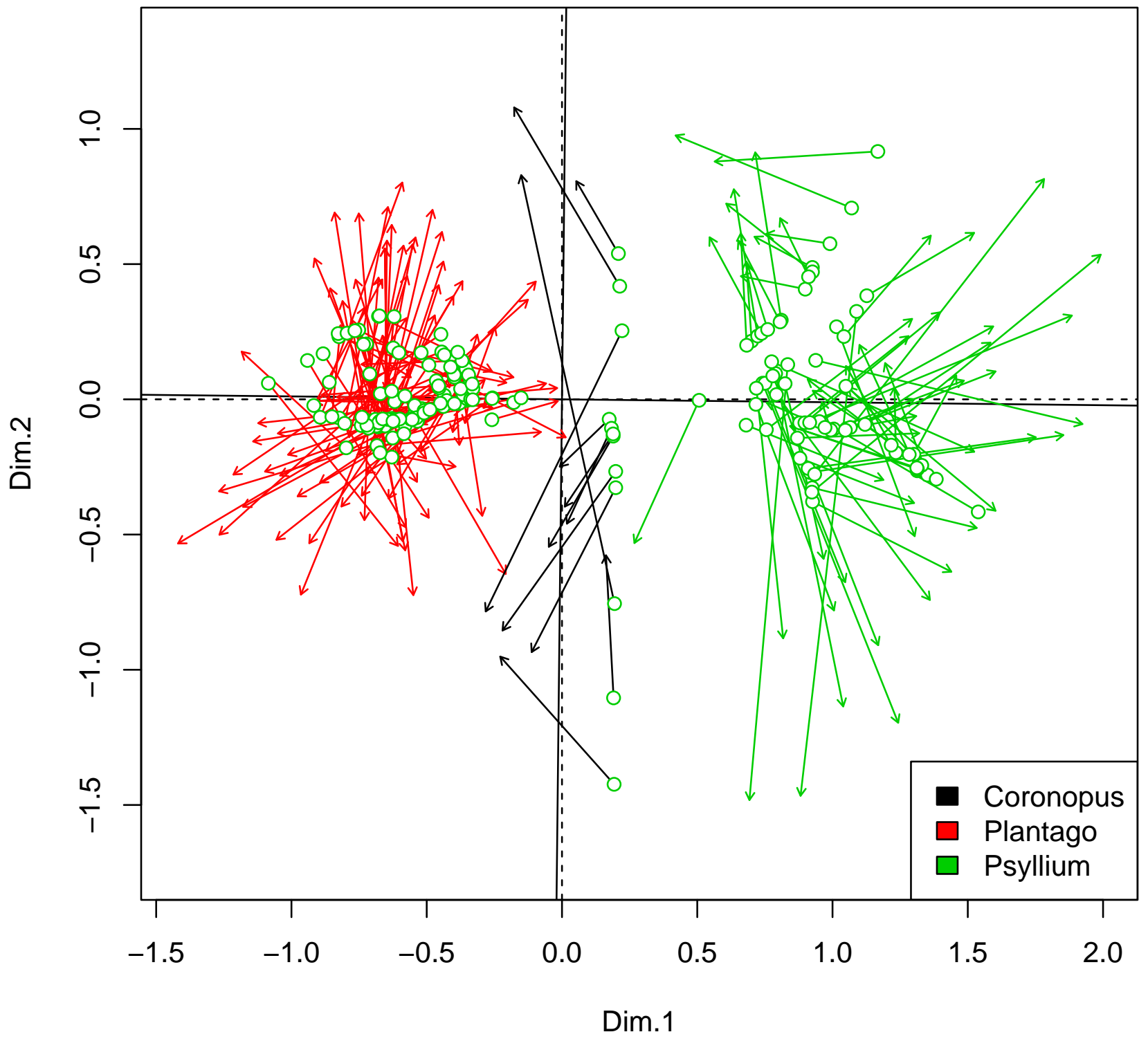




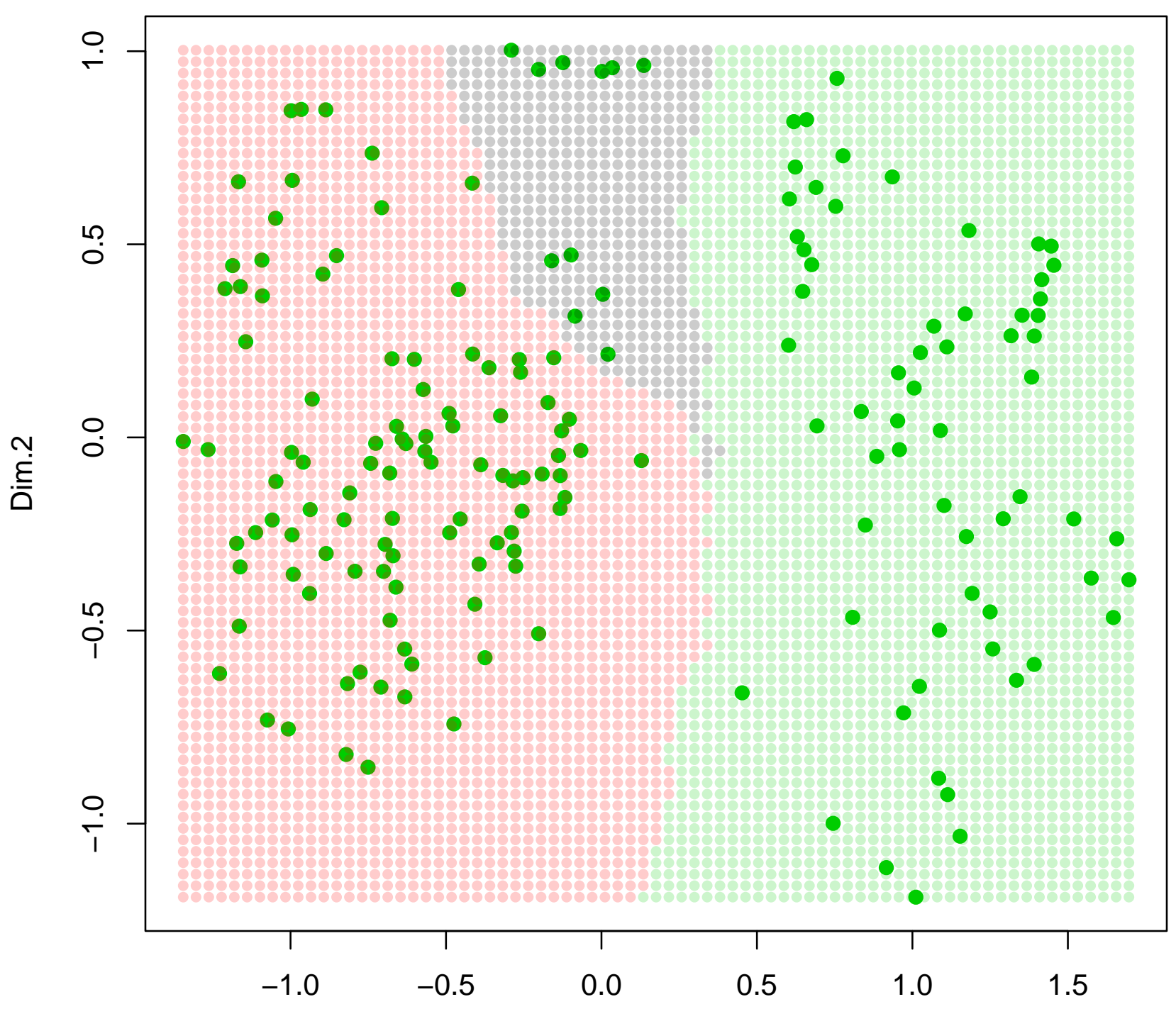

Dim. 1 


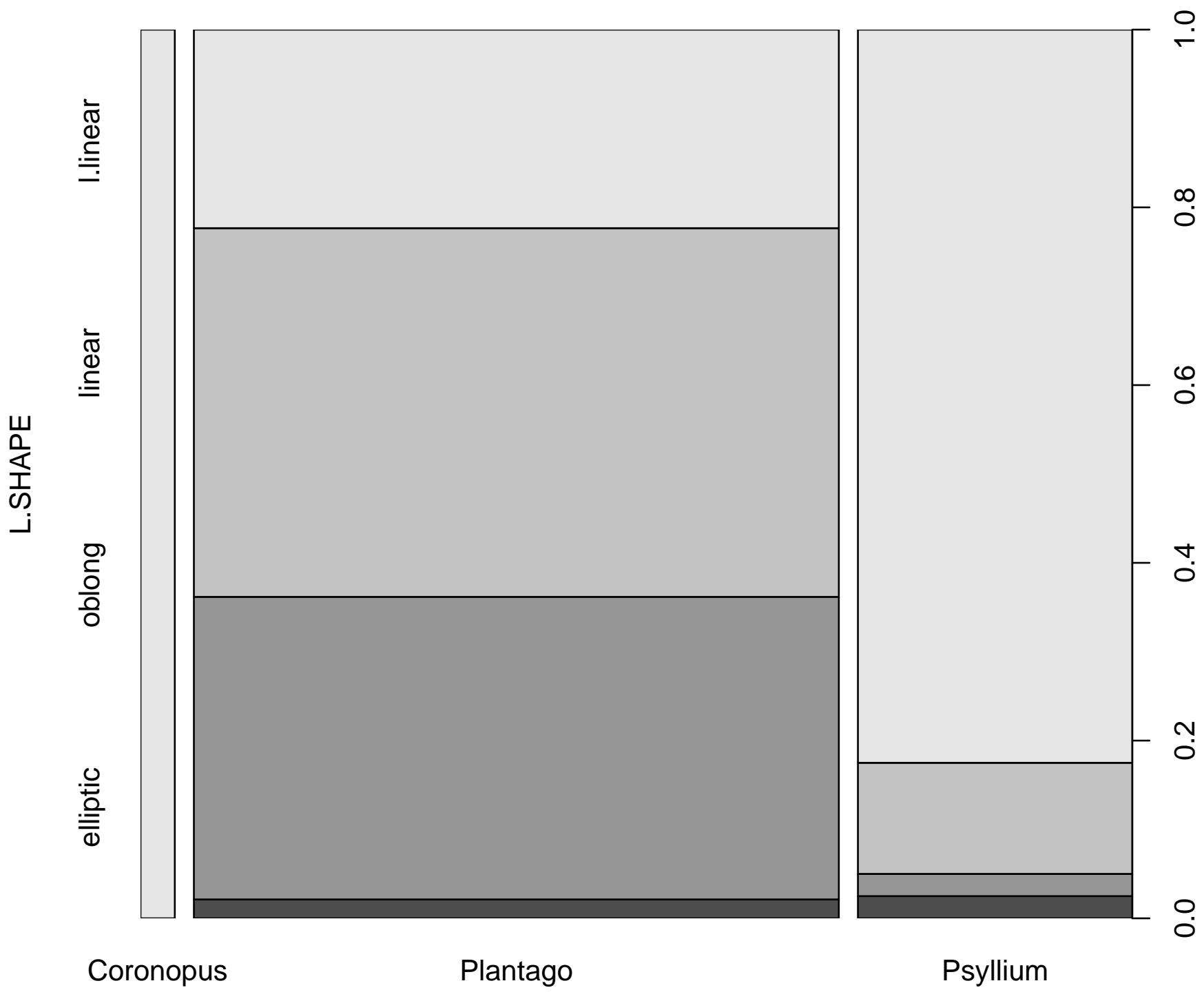


preprint (which was not certified by peer review) in the Public Domain. It is no longer restricted by copyright. An nne $n$ legally share, reuse,

remix, or adapt this material for any purpose without crediting the original auth 14 
median

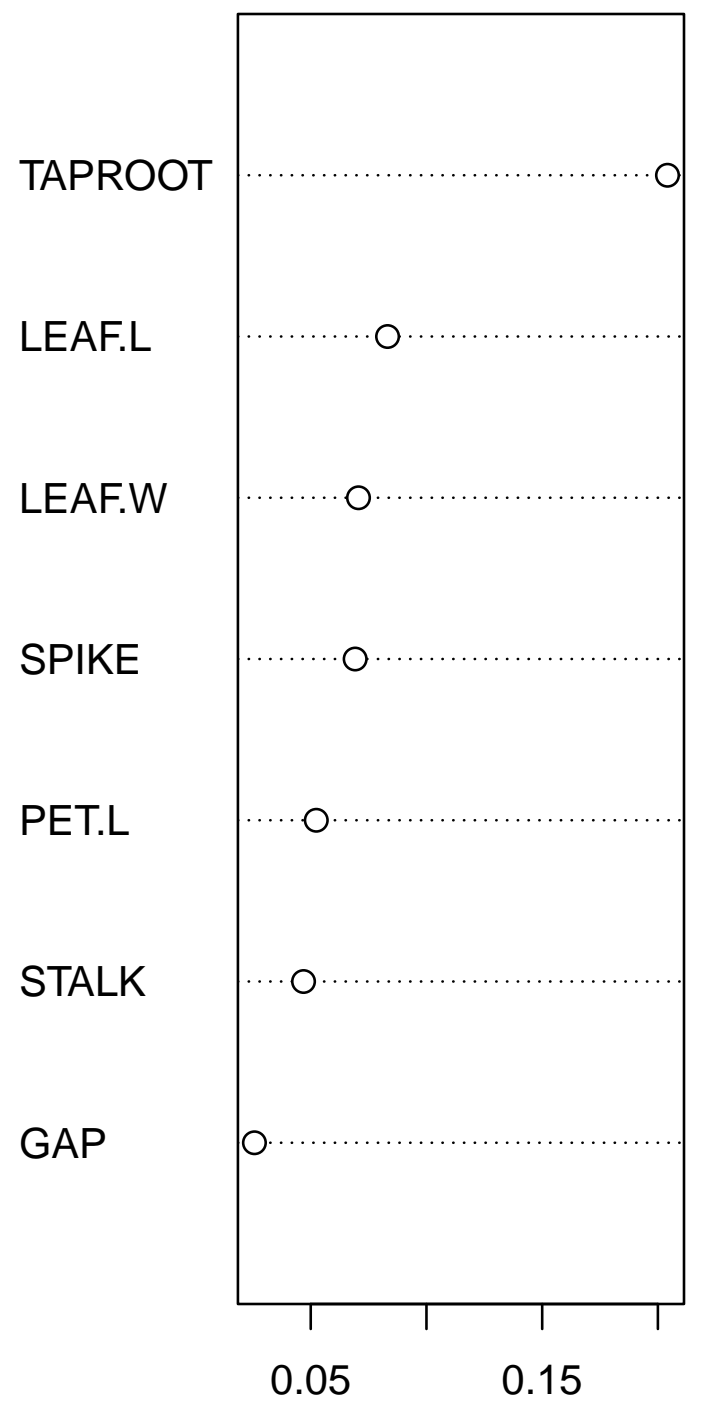

maximum

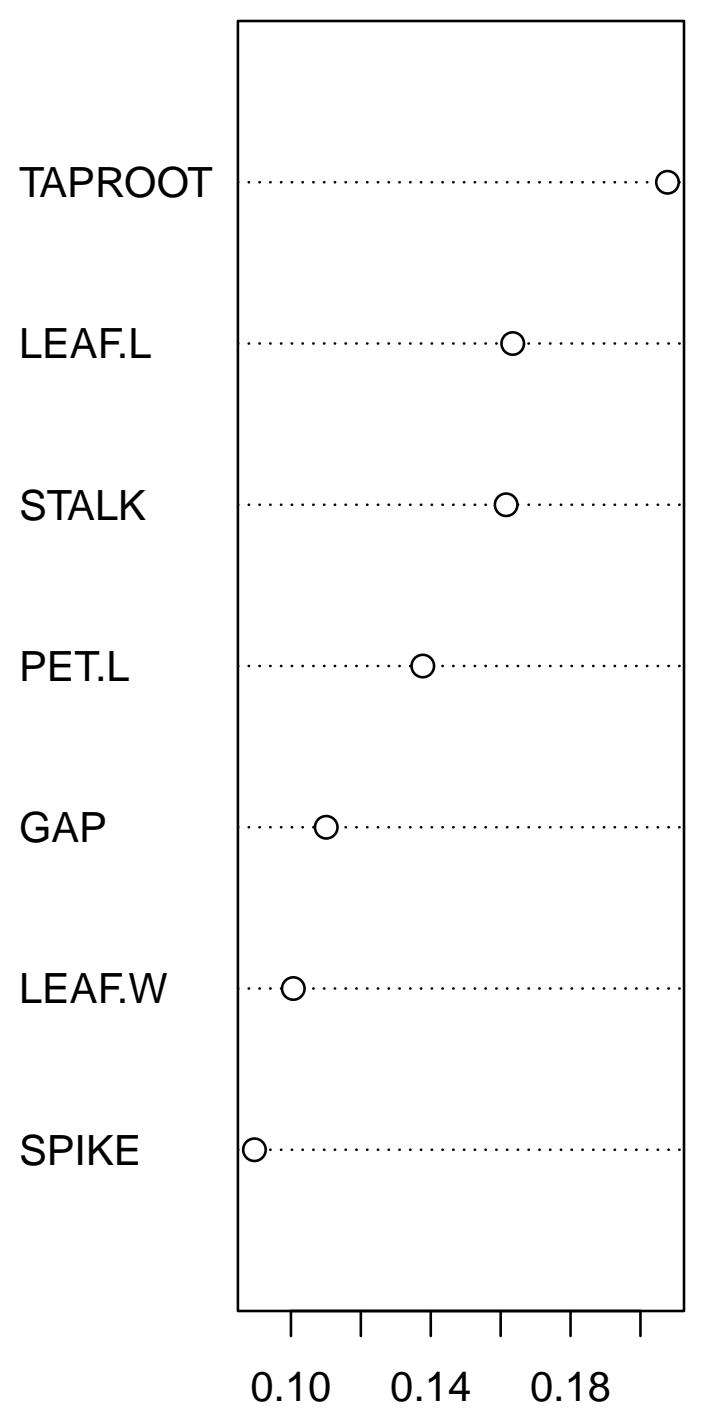


combined

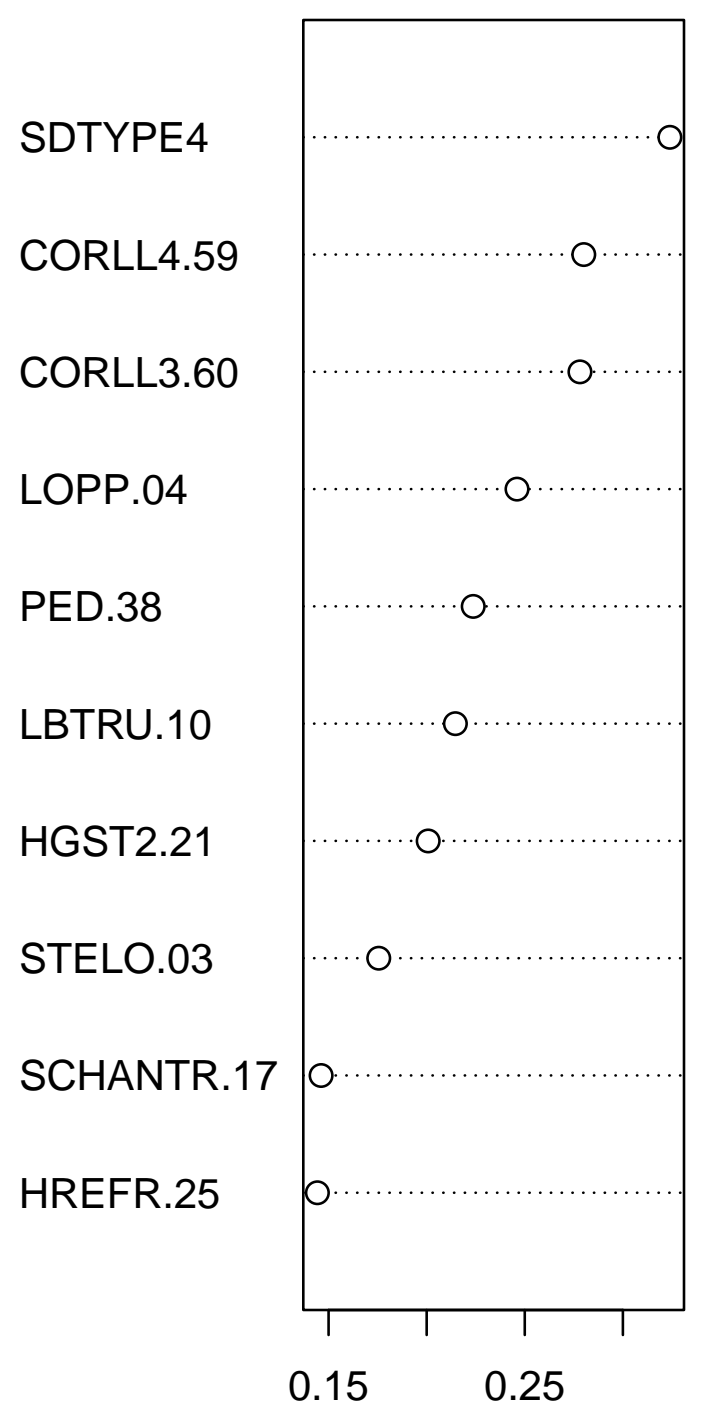

"tall"

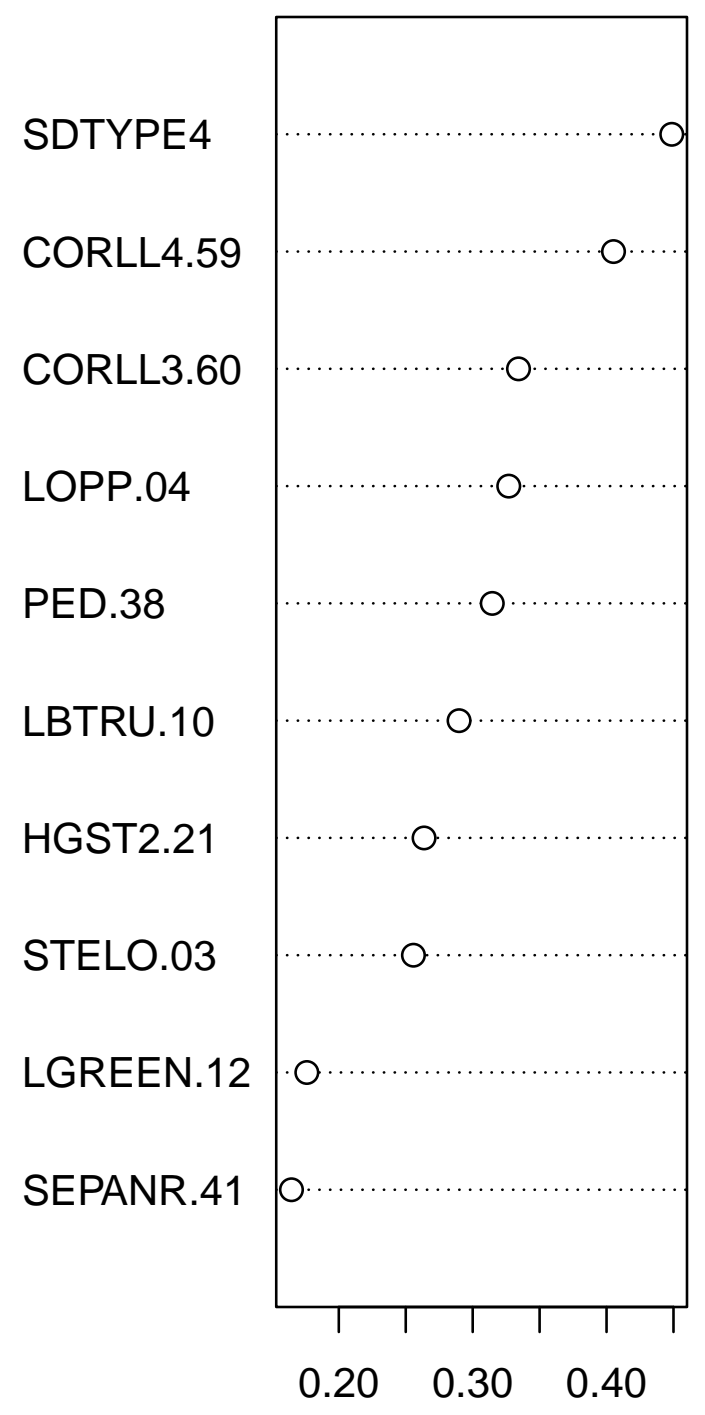




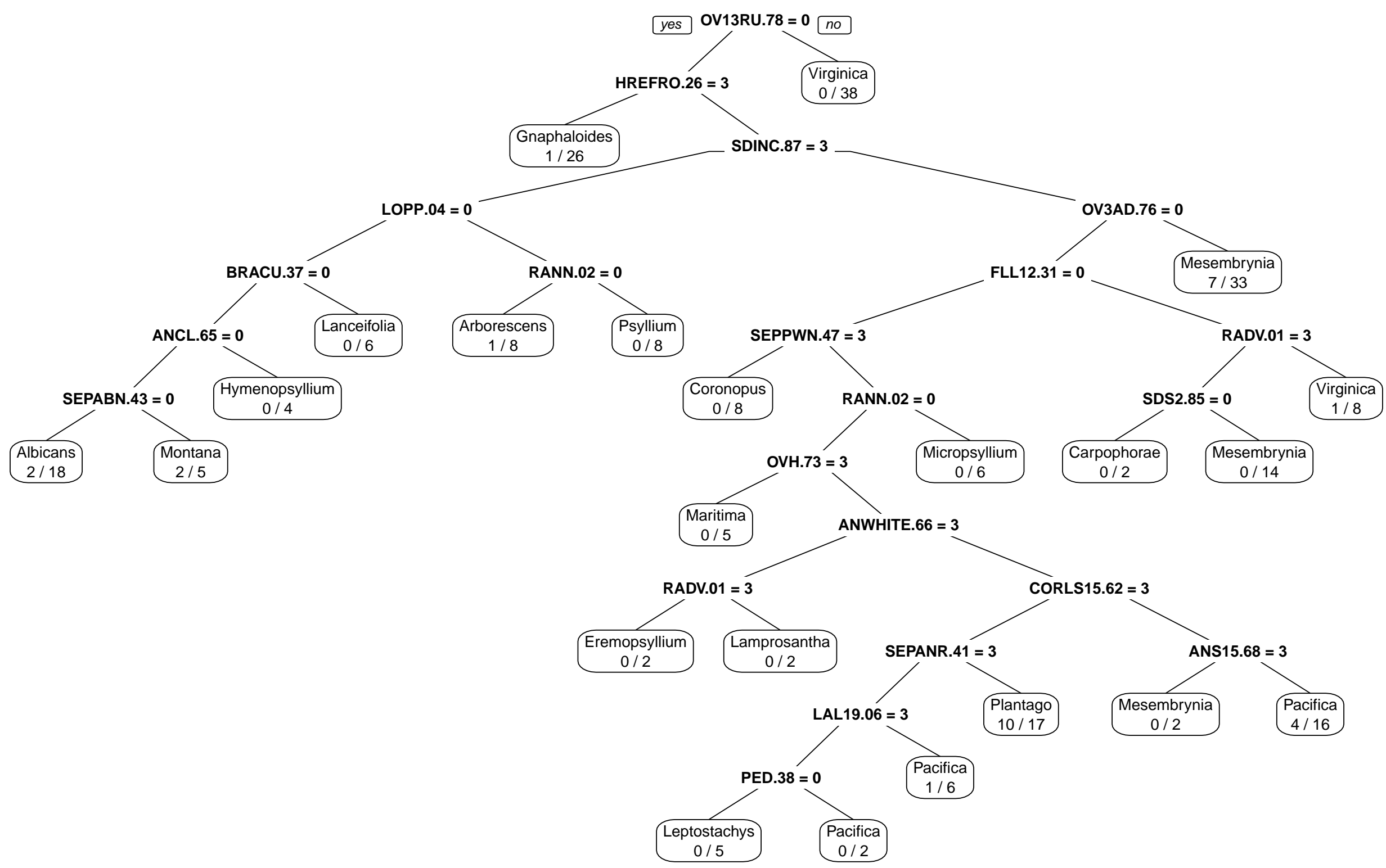




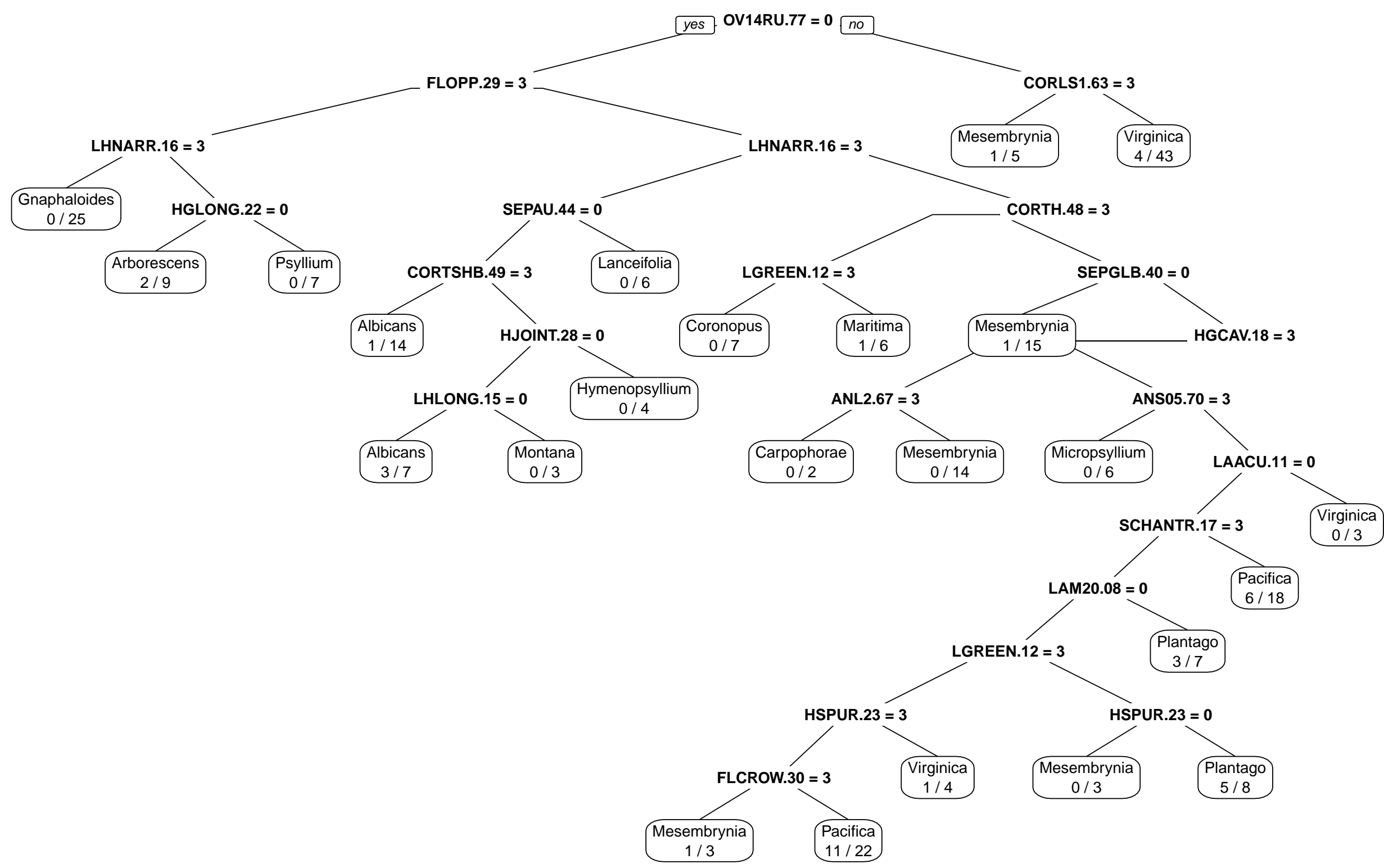

